\title{
An Assessment of the Dynamic Global Warming Impact Associated with Long- Term Emissions from Landfills
}

\author{
Yixuan Wang, James W. Levis, ${ }^{*}$ and Morton A. Barlaz
}

North Carolina State University, Department of Civil, Construction, and Environmental Engineering, Campus Box 7908, Raleigh, NC 27695-7908

*Corresponding author. Phone: (919) 515-7823; fax: (919) 515-7908; email: jwlevis@ncsu.edu

\section{Supporting Information}

\author{
Number of pages: 35 \\ Number of equations: 8 \\ Number of tables: 6
}

Number of figures: 21 


\section{Table of Contents}

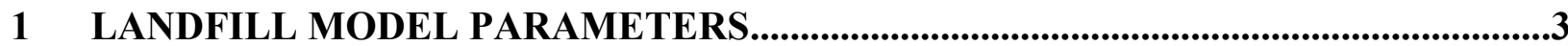

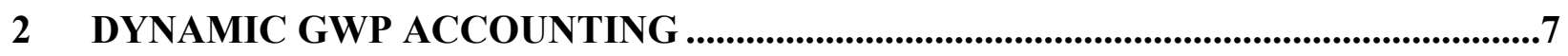

3 SUPPLEMENTAL RESULTS AND ANALYSIS .................................................9

3.1 Life-Cycle Inventory Results .......................................................................................9

3.2 Instantaneous and Cumulative Radiative Forcing .....................................................14

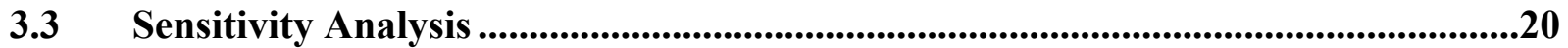

\section{List of Tables}

Table S1. Annual collection efficiencies for typical collection in flare system with a decay rate of $0.04 \mathrm{yr}^{-1}$

Table S2. Values and distributions used in the parametric and Monte Carlo sensitivity analyses for each input....

Table S3. Electricity Emission Factors for the Selected Greenhouse Gases Based on Electricity

Source.

Table S4. Electricity Selected GWP Values Based on the IPCC Reports, Time Horizon, and Treatment of Climate Carbon Feedbacks (ccfb) and Methane Oxidation (ox).....

Table S5. Comparative Results for Default Collection (gas collection starts at year 2) and Delayed Collection (gas collection starts at year 10) Cases

Table S6. A Summary Table for GWP Estimates Based on All Scenarios Considered and Evaluated in the Study.

\section{List of Figures}

Figure S1. Time-varying carbon inventory (a for $\mathrm{CO}_{2}$ and $\mathrm{b}$ for $\mathrm{CH}_{4}$ ) from biogenic and fossil origins under passive venting scenario

Figure S2. Time-varying carbon inventory (a for $\mathrm{CO}_{2}$ and b for $\mathrm{CH}_{4}$ ) results from biogenic and

fossil origins under flare scenario

Figure S3. Time-varying carbon inventory (a for $\mathrm{CO}_{2}$ and $\mathrm{b}$ for $\mathrm{CH}_{4}$ ) results from biogenic and fossil origins under energy recovery scenario

Figure S4. Final aggregate biogenic carbon inventory at time zero and at the end of 1,000 years

across all decay rate and gas control scenarios.

Figure S5. Fraction of carbon emissions released by year 100 (a) and year 20 (b) relative to the total potential carbon emissions released from landfilling $1 \mathrm{Mg}$ waste through 1,000 years. ......16 Figure S6. Time-varying atmospheric load, absolute cumulate global warming potential, and relative global warming potential for pulse release of $1 \mathrm{~kg}$ of $\mathrm{CO}_{2}$ and $\mathrm{CH}_{4}$ at time zero..... .18 Figure S7. Instantaneous radiative forcing based on Positive $\mathrm{CO}_{2} \mathrm{~b}$ accounting for four decay rates and three gas treatment scenarios.

Figure S8. Cumulative radiative forcing based on Positive $\mathrm{CO}_{2} \mathrm{~b}$ accounting for four decay rates and three gas treatment scenarios. .20

Figure S9. Instantaneous radiative forcing based on Neutral $\mathrm{CO}_{2} \mathrm{~b}$ accounting for four decay rates and three gas treatment scenarios. 
Figure S10. Cumulative radiative forcing based on Neutral $\mathrm{CO}_{2} \mathrm{~b}$ accounting for four decay rates and three gas treatment scenarios.

Figure S11. Dynamic global warming potentials for each gas control scenario and decay rate using "delayed" collection case where the installation of collection system was delayed from year 2 to year 10 .

Figure S12. Static AR4 GWP estimates for each decay rate and gas management case under "delayed" collection case and Positive $\mathrm{CO}_{2} \mathrm{~b}$ (red diamonds; $2^{\text {nd }} \mathrm{y}$-axis) and the percent difference of the dynamic and AR5 static GWP relative to the static AR4 GWP values (a - 100yr; b - 20-yr).

Figure S13. Static AR4 and AR5 GWP estimates for each decay rate and gas management case, compared with the dynamic GWP values ( $\mathrm{a}-100-\mathrm{yr}$; $\mathrm{b}-20-\mathrm{yr}$ ) using Neutral $\mathrm{CO}_{2} \mathrm{~b}$ accounting.

Figure S14. Effect of electricity source on static (AR4) and dynamic global warming potentials using Positive $\mathrm{CO}_{2} \mathrm{~b}$ accounting for four decay rates

Figure S15. Effect of electricity source on static (AR4) and dynamic global warming potentials based on Neutral $\mathrm{CO}_{2} \mathrm{~b}$ accounting for four decay rates

Figure S16. Ranges of static and dynamic 20-yr GWPs based on Positive $\mathrm{CO}_{2} \mathrm{~b}$ accounting. The default value of each input defines the baseline shown in the middle separating the lower and upper bound

Figure S17. Ranges of static and dynamic 100-yr GWPs based on Neutral $\mathrm{CO}_{2} \mathrm{~b}$ accounting. The default value of each input defines the baseline shown in the middle separating the lower and upper bound

Figure S18. Ranges of static and dynamic 20-yr GWPs based on Neutral $\mathrm{CO}_{2} \mathrm{~b}$ accounting. The default value of each input defines the baseline shown in the middle separating the lower and upper bound

Figure S19. Correlation coefficients between model inputs and GWPs associated with the landfills under the passive venting scenario, applying the Positive and Neutral $\mathrm{CO}_{2} \mathrm{~b}$ approaches based on 100-yr and 20-yr time horizon.

Figure S20. Correlation coefficients between model inputs and GWPs associated with the landfills under the flare scenario, applying the Positive and Neutral $\mathrm{CO}_{2} \mathrm{~b}$ approaches based on $100-y r$ and 20 -yr time horizon.

Figure S21. Correlation coefficients between model inputs and GWPs associated with the landfills under the energy recovery scenario, applying the Positive and Neutral $\mathrm{CO}_{2} \mathrm{~b}$ approaches based on 100-yr and 20-yr time horizon. 


\section{LANDFILL MODEL PARAMETERS}

The landfill gas collection model used a temporally averaged gas collection efficiency as described by Levis and Barlaz. ${ }^{1}$ Table S1 shows the annual collection efficiencies based on the waste age under the typical collection case of a flare and a decay rate of $0.04 \mathrm{yr}^{-1}$. To run the Monte Carlo analysis, statistical distributions were developed for each model parameter. The min-max range and distributions of each model input are presented in Table S2. Triangular distributions were used when a min-max range and reasonable "most likely" value could be identified, and uniform distributions were used when only a range was available. Table S3 shows the greenhouse gas (GHG) emission factors for different sources of electricity. 
Table S1. Annual collection efficiencies for typical collection in flare system with a decay rate of $0.04 \mathrm{yr}^{-1}$

\begin{tabular}{|c|c|c|c|c|c|}
\hline $\begin{array}{c}\text { Time Since Waste } \\
\text { Burial (years) }\end{array}$ & $\begin{array}{c}\text { Time Averaged } \\
\text { Collection Efficiency }(\%)\end{array}$ & $\begin{array}{c}\text { Time Since Waste } \\
\text { Burial (years) }\end{array}$ & $\begin{array}{c}\text { Time Averaged } \\
\text { Collection Efficiency }(\%)\end{array}$ & $\begin{array}{c}\text { Time Since Waste } \\
\text { Burial (years) }\end{array}$ & $\begin{array}{c}\text { Time Averaged } \\
\text { Collection Efficiency (\%) }\end{array}$ \\
\hline 0 & 29.4 & 27 & 63.5 & 54 & 19.4 \\
\hline 1 & 45.9 & 28 & 61.9 & 55 & 17.6 \\
\hline 2 & 60.9 & 29 & 60.3 & 56 & 15.9 \\
\hline 3 & 66.1 & 30 & 58.7 & 57 & 14.1 \\
\hline 4 & 71.3 & 31 & 57.1 & 58 & 12.4 \\
\hline 5 & 76.5 & 32 & 55.4 & 59 & 10.6 \\
\hline 6 & 76.8 & 33 & 53.8 & 60 & 8.8 \\
\hline 7 & 77.1 & 34 & 52.2 & 61 & 7.1 \\
\hline 8 & 77.4 & 35 & 50.6 & 62 & 5.3 \\
\hline 9 & 77.6 & 36 & 49.0 & 63 & 3.5 \\
\hline 10 & 77.9 & 37 & 47.4 & 64 & 1.8 \\
\hline 11 & 79.4 & 38 & 45.7 & 65 & 0.0 \\
\hline 12 & 80.7 & 39 & 44.1 & & \\
\hline 13 & 82.1 & 40 & 42.5 & & \\
\hline 14 & 83.4 & 41 & 40.9 & & \\
\hline 15 & 82.9 & 42 & 39.3 & & \\
\hline 16 & 81.3 & 43 & 37.6 & & \\
\hline 17 & 79.7 & 44 & 36.0 & & \\
\hline 18 & 78.1 & 45 & 34.4 & & \\
\hline 19 & 76.5 & 46 & 32.8 & & \\
\hline 20 & 74.9 & 47 & 31.2 & & \\
\hline 21 & 73.2 & 48 & 29.6 & & \\
\hline 22 & 71.6 & 49 & 27.9 & & \\
\hline 23 & 70.0 & 50 & 26.3 & & \\
\hline 24 & 68.4 & 51 & 24.7 & & \\
\hline 25 & 66.8 & 52 & 22.9 & & \\
\hline 26 & 65.1 & 53 & 21.2 & & \\
\hline
\end{tabular}


Table S2. Values and distributions used in the parametric and Monte Carlo sensitivity analyses for each input

\begin{tabular}{|c|c|c|c|c|c|}
\hline Inputs & Unit & Minimum & Maximum & Default & Distribution \\
\hline Moisture content ${ }^{a}$ & $\%$ & 15 & 40 & 25 & Triangular \\
\hline Decay rate ${ }^{b}$ & $\mathrm{yr}^{-1}$ & 0.02 & 0.17 & 0.04 & Triangular \\
\hline Methane yield ${ }^{c}$ & $\mathrm{~m}^{3} / \mathrm{Mg}$ wet waste & 110 & 147 & 133 & Triangular \\
\hline $\begin{array}{l}\text { Collection efficiency } \\
\text { factor }^{d}\end{array}$ & - & 0.9 & 1.1 & 1 & Triangular \\
\hline $\begin{array}{l}\text { Energy conversion } \\
\text { efficiency of } \mathrm{ICE}^{e}\end{array}$ & $\%$ & 30 & 40 & 35 & Triangular \\
\hline $\begin{array}{l}\text { Electricity emission factor } \\
\text { for } \mathrm{CO}_{2} \text {-fossif } f^{f}\end{array}$ & $\mathrm{~kg} \mathrm{CO}_{2} / \mathrm{kWh}$ & 0.568 & 1.24 & 0.711 & Triangular \\
\hline Oxidation efficiency ${ }^{g}$ & $\%$ & 10 & 40 & 10 & Triangular \\
\hline $\begin{array}{l}\text { Flare destruction } \\
\text { efficiency }^{h}\end{array}$ & $\%$ & 99.90 & 100 & & Uniform \\
\hline $\begin{array}{l}\text { Energy destruction } \\
\text { efficiency }\end{array}$ & $\%$ & 98.34 & 100 & & Uniform \\
\hline $\mathrm{CH}_{4} \mathrm{GWP}_{100}$ value $^{i}$ & $\mathrm{kgCO} 2 \mathrm{e} / \mathrm{kg}$ & 25 & 36 & & Uniform \\
\hline $\mathrm{CH}_{4} \mathrm{GWP}_{20}$ value $^{i}$ & $\mathrm{~kg} \mathrm{CO}_{2} \mathrm{e} / \mathrm{kg}$ & 72 & 87 & & Uniform \\
\hline
\end{tabular}

${ }^{a}$ The values were reported for typical moisture content for municipal solid waste in landfill from Tchobanoglous et al. (1993). ${ }^{2}$

${ }^{b}$ Adopted from IPCC (2006). ${ }^{3}$

${ }^{c}$ The values are determined based on IPCC's mass balance method for $\mathrm{CH}_{4}$ emissions from solid waste disposal. ${ }^{4}$

${ }^{d}$ Judgment based on the values for the better and worse collection case relative to the typical one. More explanation is given in the text.

${ }^{e}$ The internal combustion engine (ICE) is most commonly used in energy recovery of LFGs because of low cost and high electricity efficiency. $30 \%$ to $40 \%$ conversion efficiencies can be achieved by the ICE based on the LFG energy projects 2017 in the US. ${ }^{5}$

${ }^{f}$ From e Grid 2016 data $^{6}$

$g$ The minimum oxidation rate of $10 \%$ is recommended by the EPA's AP-42 database ${ }^{7}$ and the judgment for the maximum value $(40 \%)$ is based on Chanton et al., $2009 .^{8}$

${ }^{h}$ Judgement based on a review of the practice on methane destruction efficiency in flare devices and energy engines presented by the SCS Engineers. ${ }^{9}$

${ }^{i}$ Developed from IPCC AR4 ${ }^{10}$ and AR5 ${ }^{11}$ reports. 
Table S3. Electricity Emission Factors for the Selected Greenhouse Gases Based on Electricity Source. ${ }^{a}$

\begin{tabular}{|c|c|c|c|c|c|c|c|c|}
\hline $\begin{array}{l}\text { Electricity } \\
\text { Emission } \\
\text { Factors }\end{array}$ & Units & $\begin{array}{l}\mathrm{CO}_{2-}^{-} \\
\text {Fossil }\end{array}$ & $\begin{array}{l}\mathrm{CO}_{2}- \\
\text { Biogenic }\end{array}$ & $\begin{array}{l}\mathrm{CO}_{2-} \\
\text { Stored }\end{array}$ & $\begin{array}{l}\mathrm{CH}_{4}- \\
\text { Fossil }\end{array}$ & $\begin{array}{l}\mathrm{CH}_{4}- \\
\text { Biogenic }\end{array}$ & $\mathrm{N}_{2} \mathrm{O}$ & $\mathrm{CO}$ \\
\hline $\begin{array}{l}\text { National } \\
\text { Average }\end{array}$ & $\mathrm{kg} / \mathrm{kWh}$ & $7.11 \mathrm{E}-01$ & $1.41 \mathrm{E}-02$ & $6.38 \mathrm{E}-05$ & $1.53 \mathrm{E}-03$ & $9.01 \mathrm{E}-06$ & $2.25 \mathrm{E}-05$ & $2.78 \mathrm{E}-04$ \\
\hline Coal & $\mathrm{kg} / \mathrm{kWh}$ & $1.24 \mathrm{E}+00$ & $1.56 \mathrm{E}-03$ & $2.34 \mathrm{E}-05$ & $1.66 \mathrm{E}-03$ & $5.17 \mathrm{E}-06$ & $3.58 \mathrm{E}-05$ & $4.28 \mathrm{E}-04$ \\
\hline Natural Gas & $\mathrm{kg} / \mathrm{kWh}$ & $5.68 \mathrm{E}-01$ & $5.26 \mathrm{E}-04$ & 4.69E-06 & $3.10 \mathrm{E}-03$ & $2.78 \mathrm{E}-07$ & $1.06 \mathrm{E}-05$ & $1.43 \mathrm{E}-04$ \\
\hline $\begin{array}{l}\text { Average } \\
\text { Combustion }\end{array}$ & $\mathrm{kg} / \mathrm{kWh}$ & $1.06 \mathrm{E}+00$ & $2.10 \mathrm{E}-02$ & $8.95 \mathrm{E}-05$ & $2.27 \mathrm{E}-03$ & $1.18 \mathrm{E}-05$ & $3.32 \mathrm{E}-05$ & $3.99 \mathrm{E}-04$ \\
\hline $\mathrm{SERC}^{b}$ & $\mathrm{~kg} / \mathrm{kWh}$ & 7.19E-01 & $1.70 \mathrm{E}-02$ & $6.94 \mathrm{E}-05$ & $1.40 \mathrm{E}-03$ & $9.12 \mathrm{E}-06$ & $2.37 \mathrm{E}-05$ & $2.83 \mathrm{E}-04$ \\
\hline
\end{tabular}




\section{DYNAMIC GWP ACCOUNTING}

A time-dependent characterization factor model was implemented to estimate dynamic GWP for annual emissions released from the modeled landfill based on Levasseur et al. ${ }^{12}$ To assess the impact of the choice of static versus dynamic GWP accounting method, a set of static GWPs from IPCC AR4 and AR5 were explored along with dynamic GWPs in the analyses, as summarized in Table S4. To evaluate the dynamic GWPs, the latest data for dynamic GWP accounting were adopted from the AR5 from 2013 IPCC ${ }^{11}$ based on the updated background $\mathrm{CO}_{2}$ level of $391 \mathrm{ppmv}$, as well as the radiative efficiency and adjusted lifetime associated with each GHG. The dynamic GWP model expresses the cumulative absolute global warming potential $\left(A G W P_{\text {cum }}\right)$ caused by GHG emissions from landfills until time $t$, relative to the equivalent value for $1 \mathrm{~kg} \mathrm{CO}_{2}$ emitted at time zero. Cumulative AGWP was found by integrating the decreasing load $C(t)_{i}$ of a GHG after the pulse release over the given time period $t$, multiplied by the instantaneous radiative efficiency per $\mathrm{kg}$ substance as shown in eq (S1). Radiative efficiency per $\mathrm{kg}\left(R E_{i}, \mathrm{~W} \mathrm{~m}^{-2} \mathrm{~kg}^{-1}\right)$ defines the increase in instantaneous radiative forcing by a unit mass of a specific GHG $i$ emitted into the atmosphere. $C(t)_{i}$ is the time-varying atmospheric load measuring the fraction of the specific GHG $i$ remaining in the atmosphere after a period of time $t$ following a unit pulse release. $\mathrm{CO}_{2}$ does not have a single atmospheric lifetime and $C(t)_{\mathrm{CO}_{2}}$ is calculated using the updated Bern Carbon Cycle

model from AR5 (IPCC 2013) (eq ((S2)). For other GHGs, $C(t)_{\text {other }}$ was calculated following a first-order decay model as shown in eq (S3). $\tau$ represents the perturbation lifetime of a given GHG. Radiative efficiency and lifetime of each GHG were based on the most recent values from IPCC 2013. 
Table S4. Electricity Selected GWP Values Based on the IPCC Reports, Time Horizon, and Treatment of Climate Carbon Feedbacks (ccfb) and Methane Oxidation (ox).

\begin{tabular}{|c|c|c|c|c|c|c|}
\hline GHGs & $\begin{array}{l}\text { Lifetime }^{a} \\
\text { (years) }\end{array}$ & IPCC Report & $\begin{array}{l}\text { Climate } \\
\text { carbon } \\
\text { feedback } \\
\text { included }\end{array}$ & $\begin{array}{l}\mathrm{CH}_{4} \\
\text { oxidation to } \\
\mathrm{CO}_{2} \text { included }\end{array}$ & $\begin{array}{l}\mathrm{GWP}_{20} \\
\left(\mathrm{~kg} \mathrm{CO}_{2} \mathrm{e} / \mathrm{kg}\right)\end{array}$ & $\begin{array}{l}\mathrm{GWP}_{100} \\
\left(\mathrm{~kg} \mathrm{CO}_{2} \mathrm{e} / \mathrm{kg}\right)\end{array}$ \\
\hline $\mathrm{CO}_{2}$ & Variable $^{b}$ & Constant & & & 1 & 1 \\
\hline $\mathrm{CO}^{c}$ & $\begin{array}{l}\text { Estimated based } \\
\text { on } \mathrm{CO}_{2}\end{array}$ & Constant & & & 1.57 & 1.57 \\
\hline \multirow[t]{5}{*}{$\mathrm{CH}_{4}$} & 12.4 & AR4 & No & No & 72 & 25 \\
\hline & & AR5 & No & No & 84 & 28 \\
\hline & & AR5 & No & Yes & 85 & 30 \\
\hline & & AR5 & Yes & No & 86 & 34 \\
\hline & & AR5 & Yes & Yes & 87 & 36 \\
\hline \multirow[t]{3}{*}{$\mathrm{N}_{2} \mathrm{O}$} & 121 & AR4 & No & N/A & 289 & 298 \\
\hline & & AR5 & No & N/A & 264 & 265 \\
\hline & & AR5 & Yes & N/A & 268 & 298 \\
\hline
\end{tabular}

${ }^{a}$ Based on the most updated AR5 (Table 8.A.1) unless otherwise stated. ${ }^{11}$

${ }^{b} \mathrm{CO}_{2}$ has no single atmospheric response time because of various uptake rates of removal processes, but its decay is estimated by a sum of exponential expressions based on the Bern Carbon model (see Eq S2 in the SI). A reasonable range of the atmospheric lifetime of $\mathrm{CO}_{2}$ varies from 5 to 200 years, dependent on if the removal process is fast (e.g., dissolved in ocean) or slow (e.g., rock formation). ${ }^{13}$

${ }^{c}$ It is assumed that $\mathrm{CO}$ is oxidized to $\mathrm{CO}_{2}$ in the atmosphere, so its radiative forcing is estimated based on the amount of $\mathrm{CO}_{2}$ produced (i.e., $44.01 \mathrm{~kg} \mathrm{CO}_{2} \mathrm{~mol}^{-1} \mathrm{C} / 28.01 \mathrm{~kg} \mathrm{CO} \mathrm{mol}^{-1} \mathrm{C}=1.57 \mathrm{~kg} \mathrm{CO}_{2} / \mathrm{kg} \mathrm{CO}$ ).

$$
\begin{gathered}
A G W P(t)_{\text {cum }}=\int_{0}^{t} R E \cdot C(t) d t \\
C(t)_{C O_{2}}=0.2173+0.2240 e^{-\frac{t}{394.4}}+0.2824 e^{-\frac{t}{36.54}}+0.2763 e^{-\frac{t}{4.304}} \\
C(t)_{\text {other }}=e^{-t / \tau}
\end{gathered}
$$

The instantaneous characterization factor, $A G W P(t)_{\text {instant }}$, was obtained using eq (S4) to represent the annual warming impact induced by a unit mass of pulse emission. To obtain the instantaneous radiative forcing $R F(t)_{\text {instant }}\left(\mathrm{W} \mathrm{m}^{-2}\right)$ for annual $\mathrm{GHG}$ releases from landfills, the annual 
emissions $E_{i}(x)(\mathrm{kg})$ for the specific GHG released in year $x$ were multiplied by the characterization factor $\operatorname{AGWP}(t-x)_{\text {instant, } i}\left(\mathrm{~W} \mathrm{~m}^{-2} \mathrm{~kg}^{-1}\right)$, as shown in eq (S5). AGWP $(t-x)_{\text {instant }, i}$ characterizes the radiative forcing from time $x$ until time $t$ since gases emitted at time $x$ only contribute to the impact for $(t-x)$ years. Cumulative radiative forcing was further given by the integral of instantaneous radiative forcing through time to act as the absolute global warming potential for the long-term emissions from a landfill. Hence, the relative contribution of landfill-related GHG emissions to global warming in terms of $\mathrm{kg} \mathrm{CO}_{2} \mathrm{e}$ was obtained in eq (S6) by dividing the cumulative radiative forcing induced by cumulative and mixed landfill-associated GHGs to the reference value of a unit mass of $\mathrm{CO}_{2}$.

To reflect the state of climate science, the indirect $\mathrm{CH}_{4}$ oxidation to $\mathrm{CO}_{2}$ was added to the warming impacts for $\mathrm{CH}_{4}$, assuming $100 \%$ of $\mathrm{CH}_{4}$ is eventually converted to $\mathrm{CO}_{2}$. This indirect effect is described in eq ((S7) and (S8). $\alpha$ is the fraction of $\mathrm{CH}_{4}$ oxidized to $\mathrm{CO}_{2}(\alpha=1$ in the study). The pulse emission ratio $\frac{E_{-} \text {mass }(t)_{\mathrm{CO}_{2}}}{E_{-} \text {mass }\left(t_{\mathrm{CH}_{4}}\right.}\left(\mathrm{kg} \mathrm{CO}_{2} / \mathrm{kg} \mathrm{CH}_{4}\right)$ describes the instantaneous mass load fraction of $\mathrm{CO}_{2}$ emissions from $\mathrm{CH}_{4}$ oxidation to the remaining load of $\mathrm{CH}_{4}$ at time $t$, where the massbased rates $E_{-}$mass $(t)$ is converted from the volume rates $E_{-}$volume $(t)$ (ppmv) of $\mathrm{CO}_{2}$ and $\mathrm{CH}_{4}$ , which were reported by Boucher et al. ${ }^{14}$ The indirect cumulative characterization factor $\mathrm{AGWP}(t){ }_{\text {cum, }}^{\text {indire }} \mathrm{CO}_{2}$ is then calculated using eq (S8). $\mathrm{C}(t-x)_{\mathrm{CO}_{2}}$ represents the atmospheric load of $\mathrm{CO}_{2}$ at time $t$ from a pulse release of $1 \mathrm{~kg} \mathrm{CH}_{4}$ at time $x$.

$$
\begin{gathered}
A G W P(t)_{\text {instant }}=\int_{t-1}^{t} R E \cdot C(t) d t=A G W P_{\text {cum }}(t)-A G W P_{\text {cum }}(t-1) \\
R F(t)_{\text {instant }}=\sum_{i} \sum_{x=0}^{t} E_{i}(x) \cdot A G W P(t-x)_{\text {instant }, i}
\end{gathered}
$$




$$
\begin{aligned}
& G W P_{i}(T H)=\frac{A G W P_{\text {cum }, i}(T H)}{A G W P_{{\text {cum }, \mathrm{CO}_{2}}(T H)}}=\frac{R E_{i} \int_{0}^{T H} C(t)_{i} d t}{R E_{C O_{2}} \int_{0}^{T H} C(t)_{C O_{2}} d t} \\
& \frac{E_{-} \operatorname{mass}(t)_{\mathrm{CO}_{2}}}{E_{-} \operatorname{mass}(t)_{C \mathrm{CH}_{4}}}=\frac{E_{-} \text {volume }(t)_{\mathrm{CO}_{2}}}{E_{-} \text {volume }(t)_{\mathrm{CH}_{4}}} \cdot \frac{M W_{\mathrm{CO}_{2}}}{M W_{\mathrm{CH}_{4}}}=\left(\alpha \cdot \tau^{-1} \cdot e^{-\frac{t}{\tau}}\right) \cdot \frac{M W_{\mathrm{CO}_{2}}}{M W_{\mathrm{CH}_{4}}} \\
& \operatorname{AGWP}(t) \underset{\text { cum, } \mathrm{CO}_{2}}{\text { indirect }}=\int_{0}^{t} R E_{\mathrm{CO}_{2}}\left(\int_{0}^{t} \frac{E_{\operatorname{mass}(x) \mathrm{CO}_{2}}}{E_{\operatorname{mass}(x) \mathrm{CH}_{4}}} \cdot C(t-x)_{\mathrm{CO}_{2}} d x\right) d t
\end{aligned}
$$

\section{SUPPLEMENTAL RESULTS AND ANALYSIS}

\subsection{Life-Cycle Inventory Results}

Figure $\mathrm{S} 1-\mathrm{S} 3$ show emissions of $\mathrm{CH}_{4}$ and $\mathrm{CO}_{2}$ from landfilling $1 \mathrm{Mg}$ waste, based on passive venting, flare and energy recovery scenarios, respectively. Landfills with larger bulk decay rates concentrate more emissions in a shorter timeframe, while those with lower decay rate delay their emissions. Figure $\mathrm{S} 4$ shows the mass of biogenic $\mathrm{C}$ stored, emitted as $\mathrm{CH}_{4}$, and emitted as $\mathrm{CO}_{2}$ in each scenario, and Figure $\mathrm{S} 5$ shows the fraction of $\mathrm{CH}_{4}$ and $\mathrm{CO}_{2}$ emissions that occur before year 20 and year 100 for each scenario. The optimal $\mathrm{CO}_{2}$ emissions points shown in Figures $\mathrm{S} 2$ and S3 occur due to changes in average landfill gas collection efficiency over time (Table S1). 
a. Time-Varying $\mathrm{CO}_{2}$ Inventory, Passive Venting

- Biogenic $\mathrm{CO} 2,0.02 \mathrm{yr}-1$

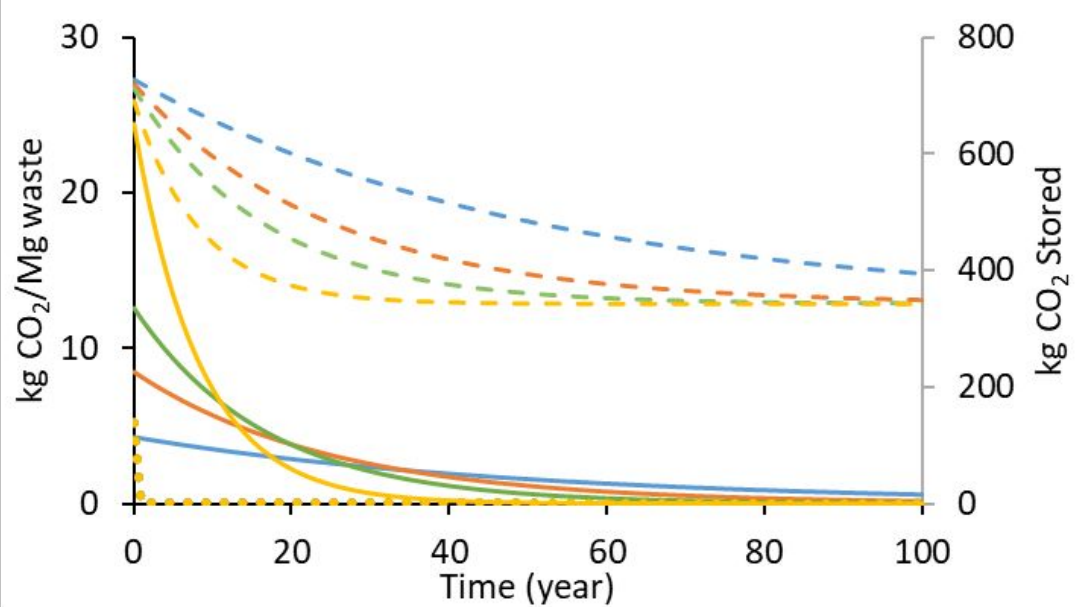

.... Fossil CO2, $0.02 \mathrm{yr}-1$

Biogenic $\mathrm{CO} 2,0.04 \mathrm{yr}-1$

.... Fossil CO2, 0.04 yr-1

Biogenic $\mathrm{CO} 2,0.06 \mathrm{yr}-1$

..... Fossil CO2, 0.06 yr-1

—Biogenic $\mathrm{CO} 2,0.12 \mathrm{yr}-1$

$\ldots$ Fossil CO2, 0.12 yr-1

- - - Stored CO2, $0.02 \mathrm{yr}-1$

- - - Stored CO2, 0.04 yr-1

- - - Stored CO2, $0.06 \mathrm{yr}-1$

- - - Stored CO2, 0.12 yr-1

b. Time-varying $\mathrm{CH}_{4}$ Inventory, Passive Venting

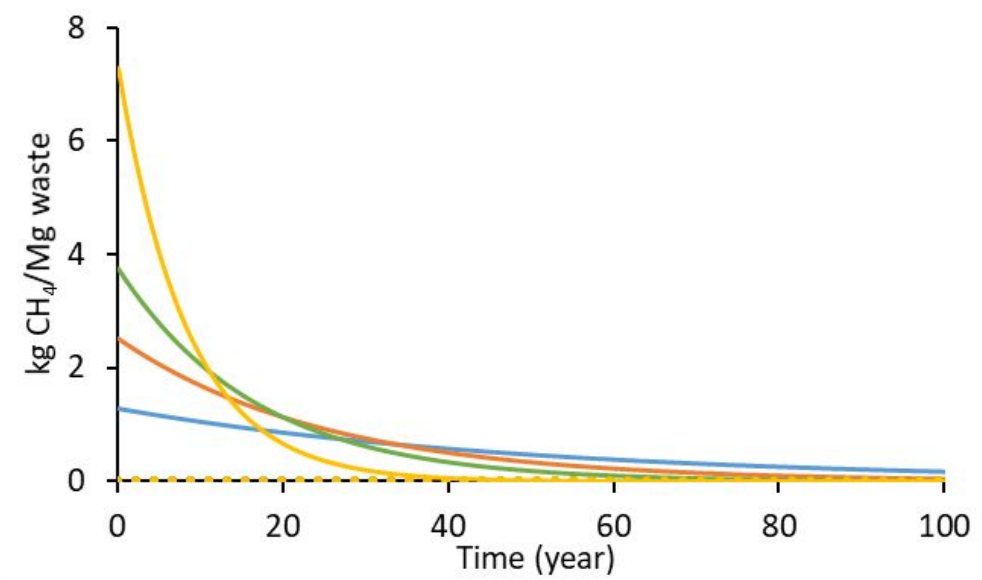

— Biogenic $\mathrm{CH} 4,0.02 \mathrm{yr}-1$

-... Fossil $\mathrm{CH} 4,0.02 \mathrm{yr}-1$

— Biogenic $\mathrm{CH} 4,0.04 \mathrm{yr}-1$

-... Fossil $\mathrm{CH} 4,0.04 \mathrm{yr}-1$

Biogenic $\mathrm{CH} 4,0.06 \mathrm{yr}-1$

-... Fossil CH4, $0.06 \mathrm{yr}-1$

- Biogenic $\mathrm{CH} 4,0.12 \mathrm{yr}-1$

$\ldots$ Fossil $\mathrm{CH} 4,0.12 \mathrm{yr}-1$

Figure S1. Time-varying carbon inventory (a for $\mathrm{CO}_{2}$ and b for $\mathrm{CH}_{4}$ ) from biogenic and fossil origins under passive venting scenario. Fossil $\mathrm{CH}_{4}$ emissions are negligible and are not shown. 
a. Time-varying $\mathrm{CO}_{2}$ Inventory, Flare

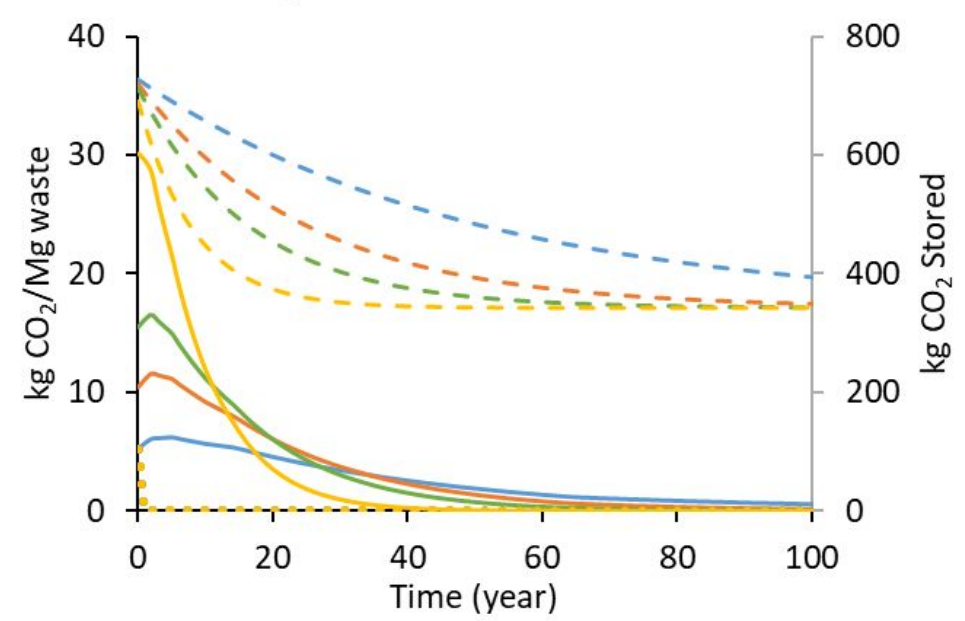

— Biogenic $\mathrm{CO} 2,0.02 \mathrm{yr}-1$

.... Fossil CO2, $0.02 \mathrm{yr}-1$

_Biogenic $\mathrm{CO} 2,0.04 \mathrm{yr}-1$

..... Fossil CO2, $0.04 \mathrm{yr}-1$

— Biogenic $\mathrm{CO} 2,0.06 \mathrm{yr}-1$

.... Fossil CO2, $0.06 \mathrm{yr}-1$

Biogenic $\mathrm{CO} 2,0.12 \mathrm{yr}-1$

..... Fossil CO2, $0.12 \mathrm{yr}-1$

- - - Stored $\mathrm{CO} 2,0.02 \mathrm{yr}-1$

- - - Stored CO2, $0.04 \mathrm{yr}-1$

- - - Stored CO2, $0.06 \mathrm{yr}-1$

- - - Stored CO2, 0.12 yr-1

b. Time-varying $\mathrm{CH}_{4}$ Inventory, Flare

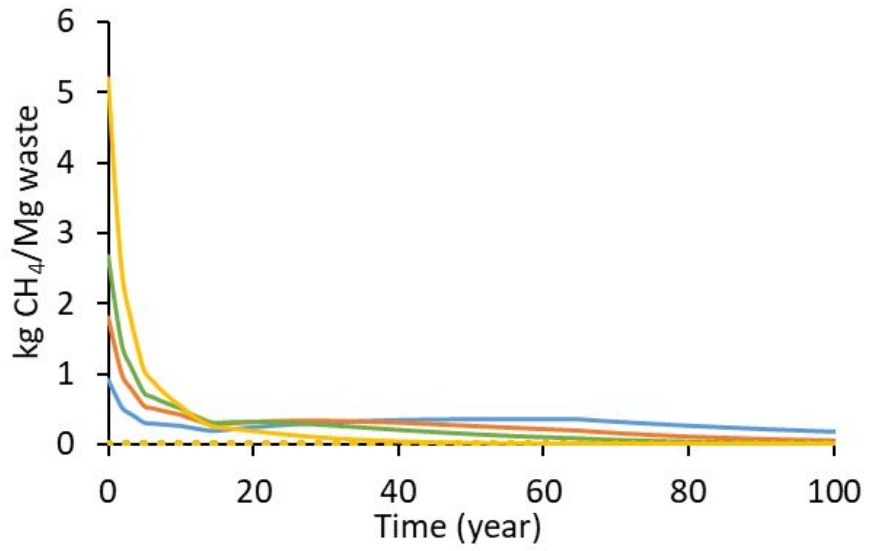

Biogenic $\mathrm{CH} 4,0.02 \mathrm{yr}-1$

•... Fossil CH4, 0.02 yr-1

— Biogenic $\mathrm{CH} 4,0.04 \mathrm{yr}-1$

..... Fossil CH4, 0.04 yr-1

Biogenic $\mathrm{CH} 4,0.06$ yr-1

… Fossil CH4, 0.06 yr-1

— Biogenic $\mathrm{CH} 4,0.12 \mathrm{yr}-1$

.... Fossil $\mathrm{CH} 4,0.12 \mathrm{yr}-1$

Figure S2. Time-varying carbon inventory (a for $\mathrm{CO}_{2}$ and $\mathrm{b}$ for $\mathrm{CH}_{4}$ ) results from biogenic and fossil origins under flare scenario. Fossil $\mathrm{CH}_{4}$ emissions are negligible and not shown. 
a. Time-varying $\mathrm{CO}_{2}$ Inventory, Energy Recovery

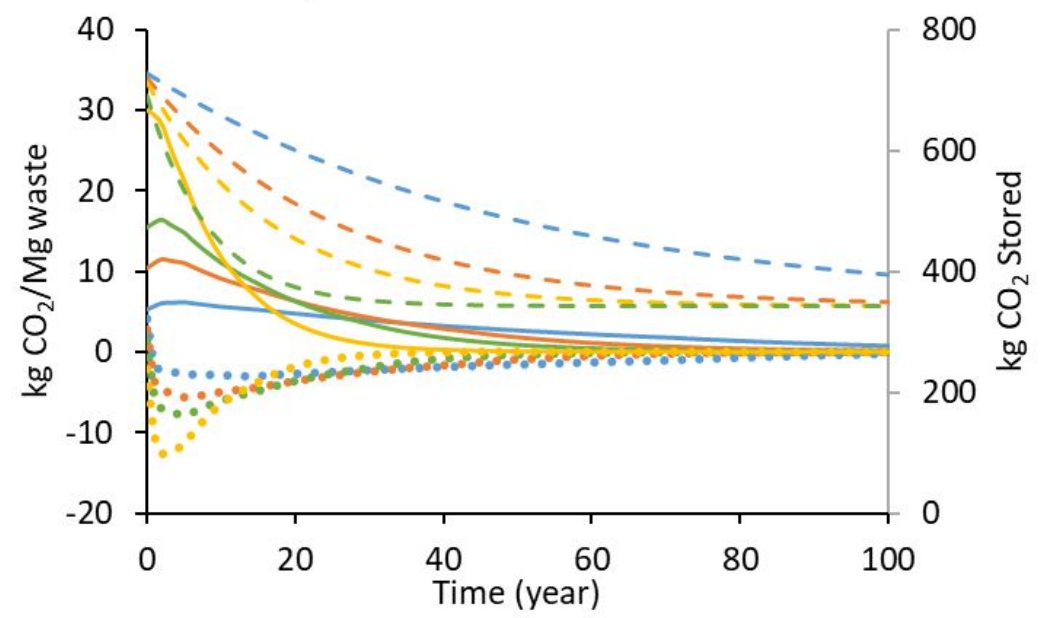

$$
\begin{aligned}
& \text { _ Biogenic } \mathrm{CO} 2,0.02 \mathrm{yr}-1 \\
& \text {.... Fossil CO2, } 0.02 \text { yr-1 } \\
& \text { — Biogenic } \mathrm{CO} 2,0.04 \mathrm{yr}-1 \\
& \text {..... Fossil CO2, } 0.04 \mathrm{yr}-1 \\
& \text { - Biogenic } \mathrm{CO} 2,0.06 \mathrm{yr}-1 \\
& \text {..... Fossil CO2, } 0.06 \mathrm{yr}-1 \\
& \text { — Biogenic } \mathrm{CO} 2,0.12 \mathrm{yr}-1 \\
& \text {..... Fossil CO2, } 0.12 \mathrm{yr}-1 \\
& \text { - - - Stored CO2, } 0.02 \text { yr-1 } \\
& \text { - - - Stored CO2, } 0.04 \mathrm{yr}-1 \\
& \text { - - - Stored CO2, } 0.06 \mathrm{yr}-1 \\
& \text { - - - Store } \mathrm{CO} 2,0.12 \mathrm{yr}-1
\end{aligned}
$$

b. Time-varying $\mathrm{CH}_{4}$ Inventory, Energy Recovery

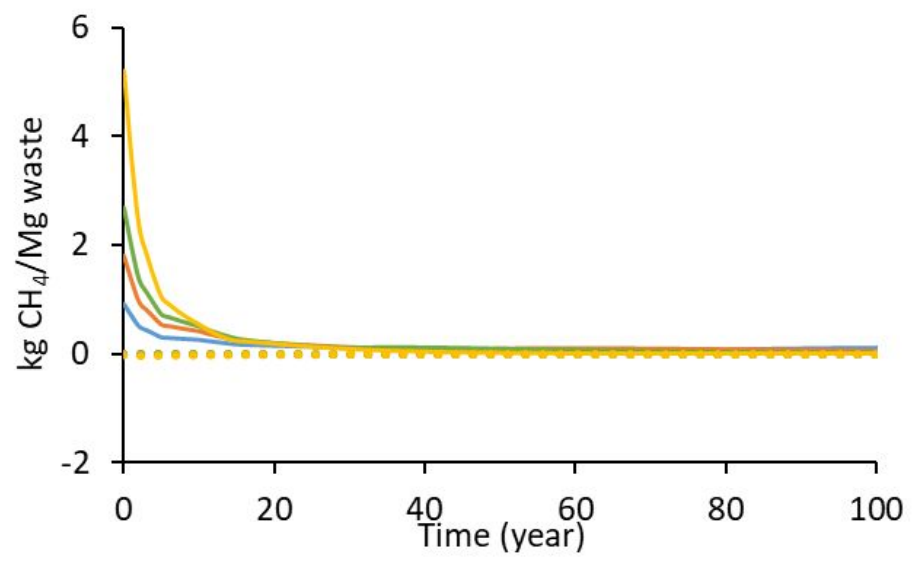

- Biogenic $\mathrm{CH} 4,0.02 \mathrm{yr}-1$

-... Fossil CH4, 0.02 yr-1

—Biogenic $\mathrm{CH} 4,0.04 \mathrm{yr}-1$

..... Fossil $\mathrm{CH} 4,0.04 \mathrm{yr}-1$

Biogenic $\mathrm{CH} 4,0.06 \mathrm{yr}-1$

•... Fossil CH4, $0.06 \mathrm{yr}-1$

Biogenic $\mathrm{CH} 4,0.12 \mathrm{yr}-1$

$\ldots$ Fossil $\mathrm{CH} 4,0.12 \mathrm{yr}-1$

Figure S3. Time-varying carbon inventory (a for $\mathrm{CO}_{2}$ and $\mathrm{b}$ for $\mathrm{CH}_{4}$ ) results from biogenic and fossil origins under energy recovery scenario. Fossil $\mathrm{CH}_{4}$ emission are negligible and not shown. 


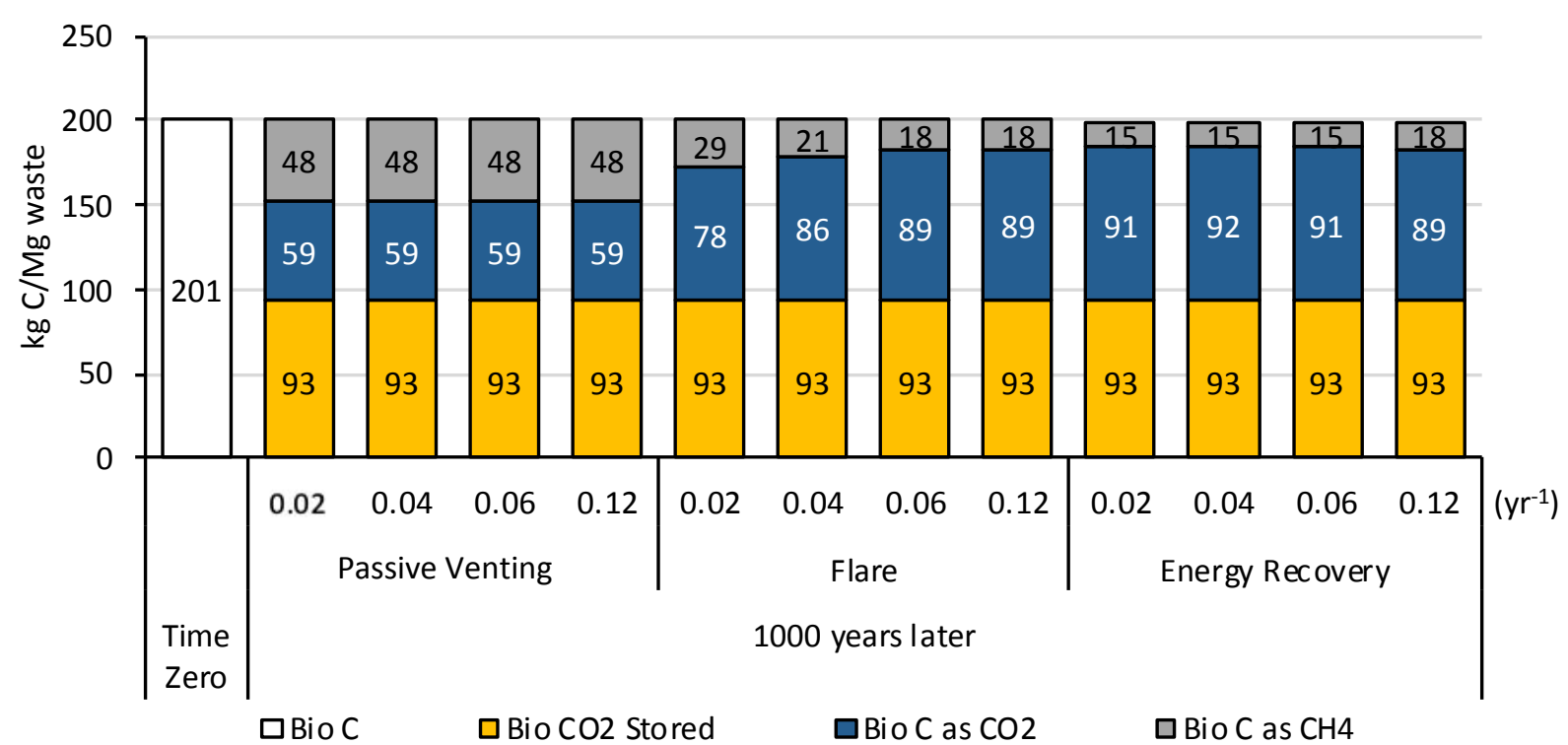

Figure S4. Final aggregate biogenic carbon inventory at time zero and at the end of 1,000 years across all decay rate and gas control scenarios.

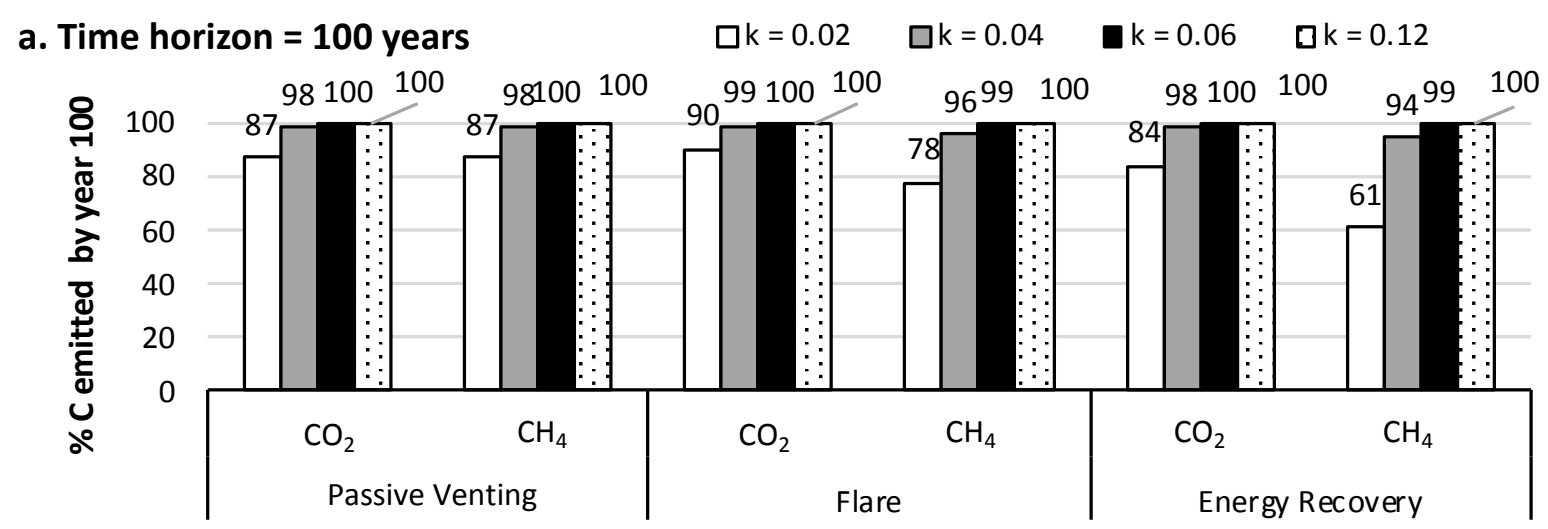

\section{b. Time horizon $=\mathbf{2 0}$ years}

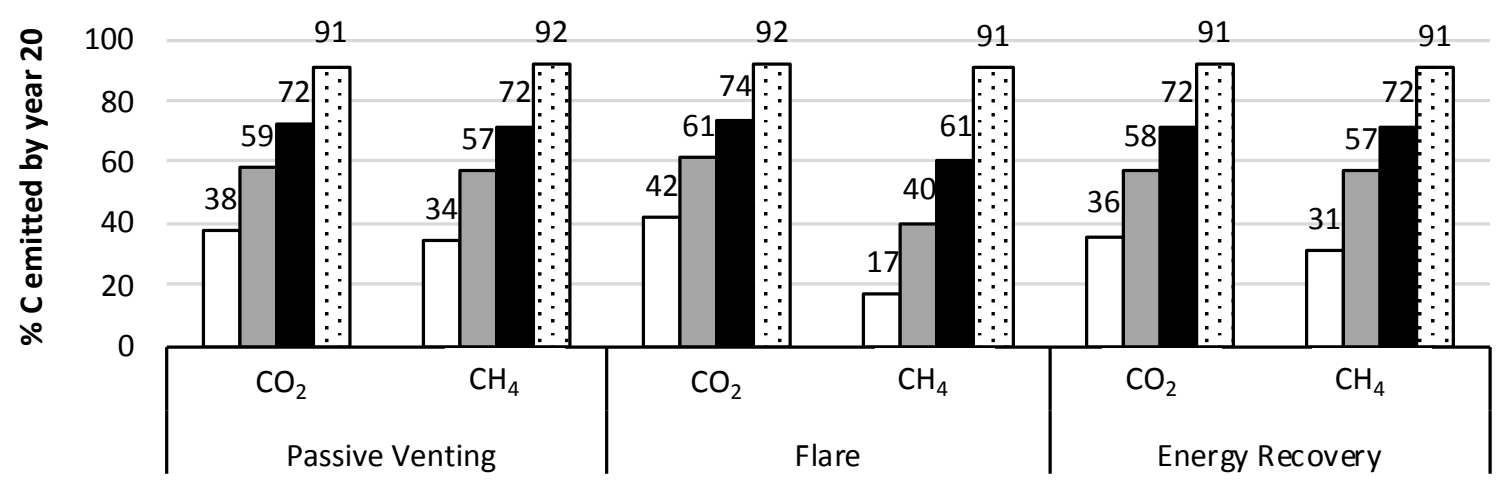

Figure S5. Fraction of carbon emissions released by year 100 (a) and year 20 (b) relative to the total potential carbon emissions released from landfilling $1 \mathrm{Mg}$ waste through 1,000 years. 


\subsection{Instantaneous and Cumulative Radiative Forcing}

The absolute global warming impacts (instantaneous impact at each time step and cumulative impact integrated until the set timeframe) from the annual pulse GHG release were modeled for the developed landfill. Figure S6 illustrates the temporal effect on atmospheric load, absolute cumulative GWPs, and GWPs relative to $\mathrm{CO}_{2}$ for $1 \mathrm{~kg}$ of pulse emissions of $\mathrm{CO}_{2}$ and $\mathrm{CH}_{4}$. Figure S7 and Figure S9 show the results for the instantaneous radiative forcing based on Positive and Neutral $\mathrm{CO}_{2} \mathrm{~b}$ accounting, respectively, indicating that the heating impact hits the peak early in a landfill's life due to the dominant GHG emissions released before collection starts, after which the impact drops due to the relatively short lifetime of methane. Then the long-lived and cumulative $\mathrm{CO}_{2}$ drives the curve to converge slowly to equilibrium. When $\mathrm{k}=0.02 \mathrm{yr}^{-1}$, the dual peaks are because collection efficiency reaches its peak at year 71 after which the impacts go up again and the energy system is cut off at year 122 which the impacts decrease. Figure S8 and Figure S10 present the cumulative radiative forcing given by integrating the instantaneous impacts over time based on Positive and Neutral $\mathrm{CO}_{2} \mathrm{~b}$ accounting, respectively. 

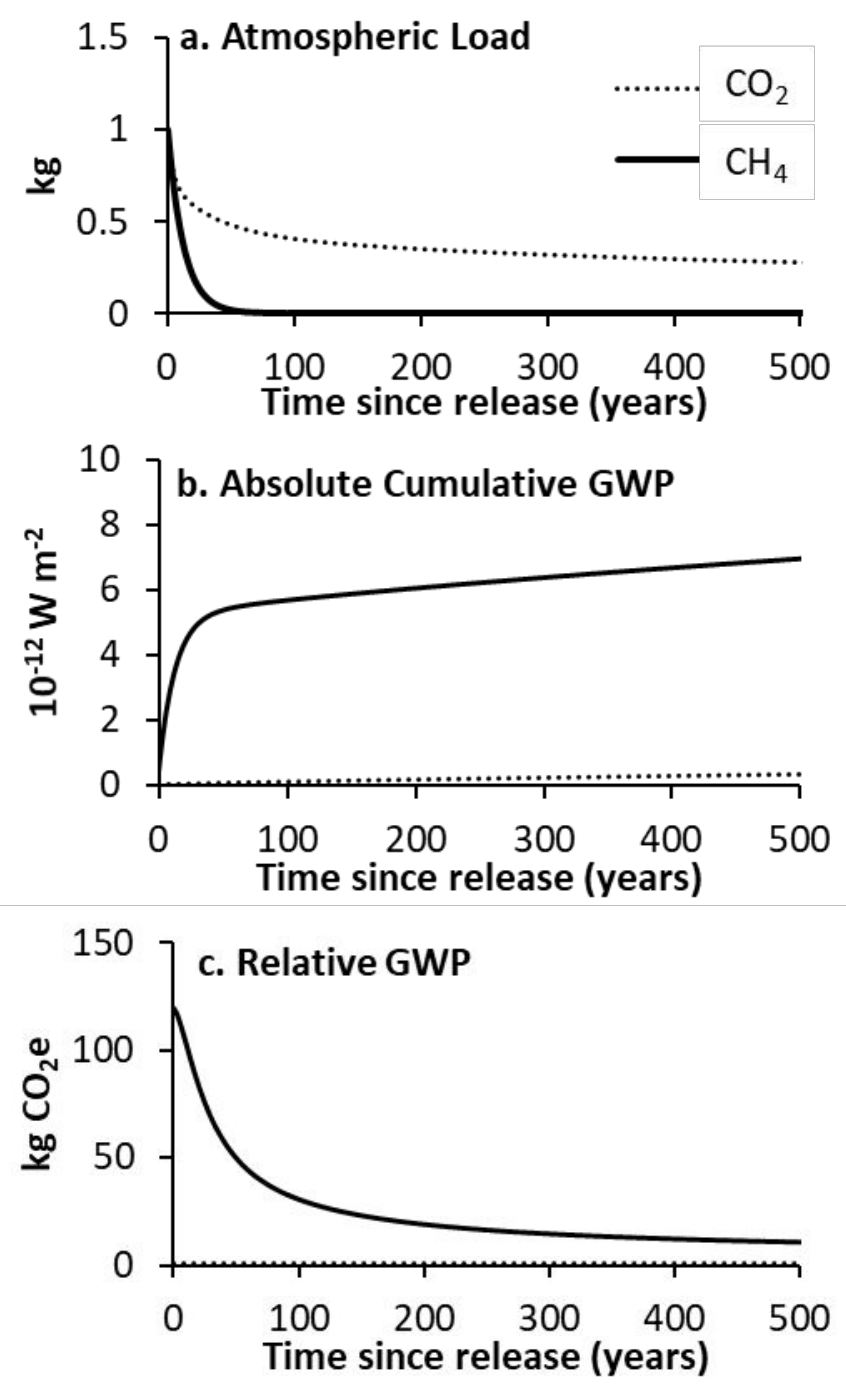

Figure S6. Time-varying atmospheric load, absolute cumulate global warming potential, and relative global warming potential for pulse release of $1 \mathrm{~kg}$ of $\mathrm{CO}_{2}$ and $\mathrm{CH}_{4}$ at time zero 

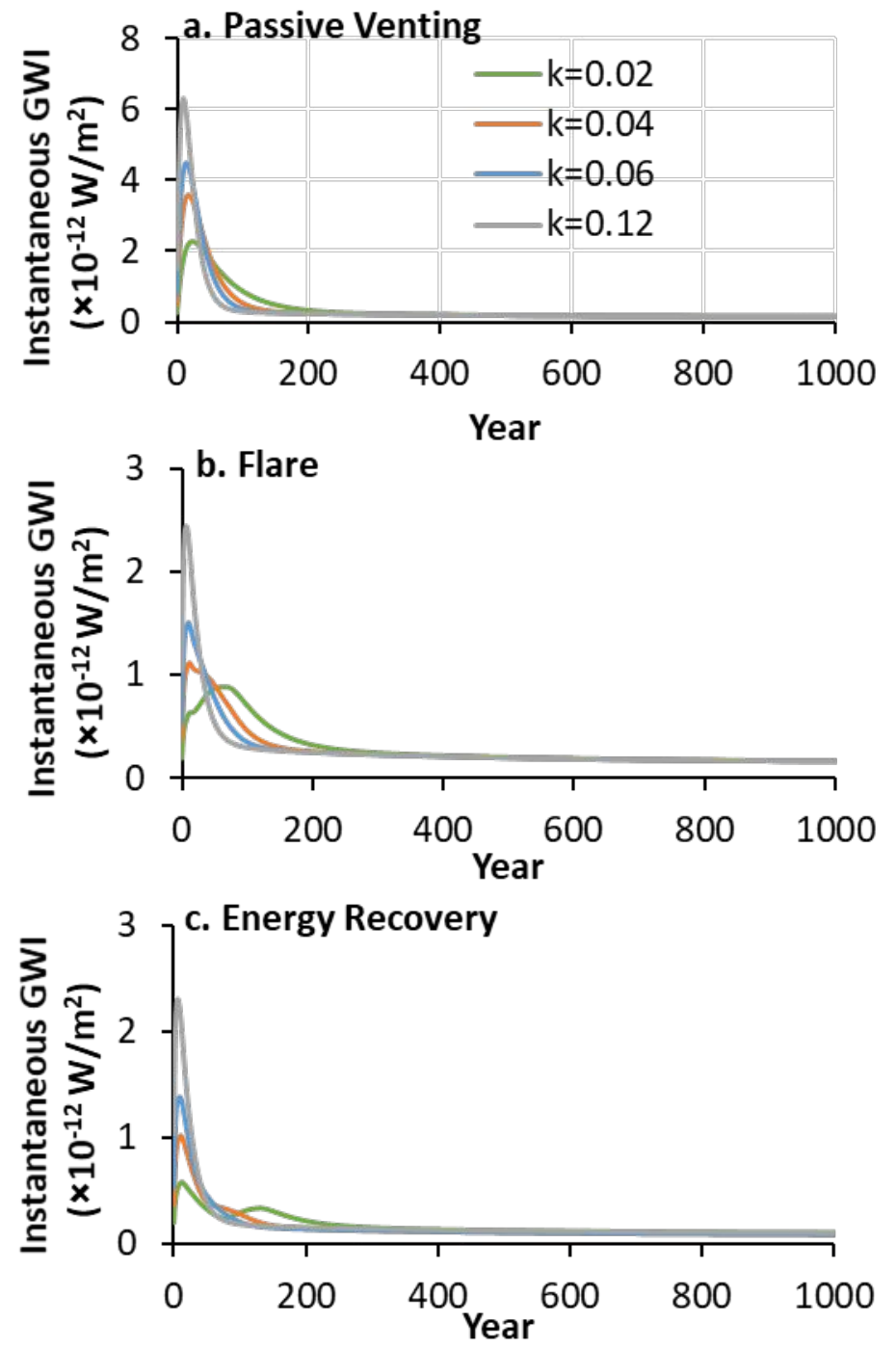

Figure S7. Instantaneous radiative forcing based on Positive $\mathrm{CO}_{2} \mathrm{~b}$ accounting for four decay rates and three gas treatment scenarios. 

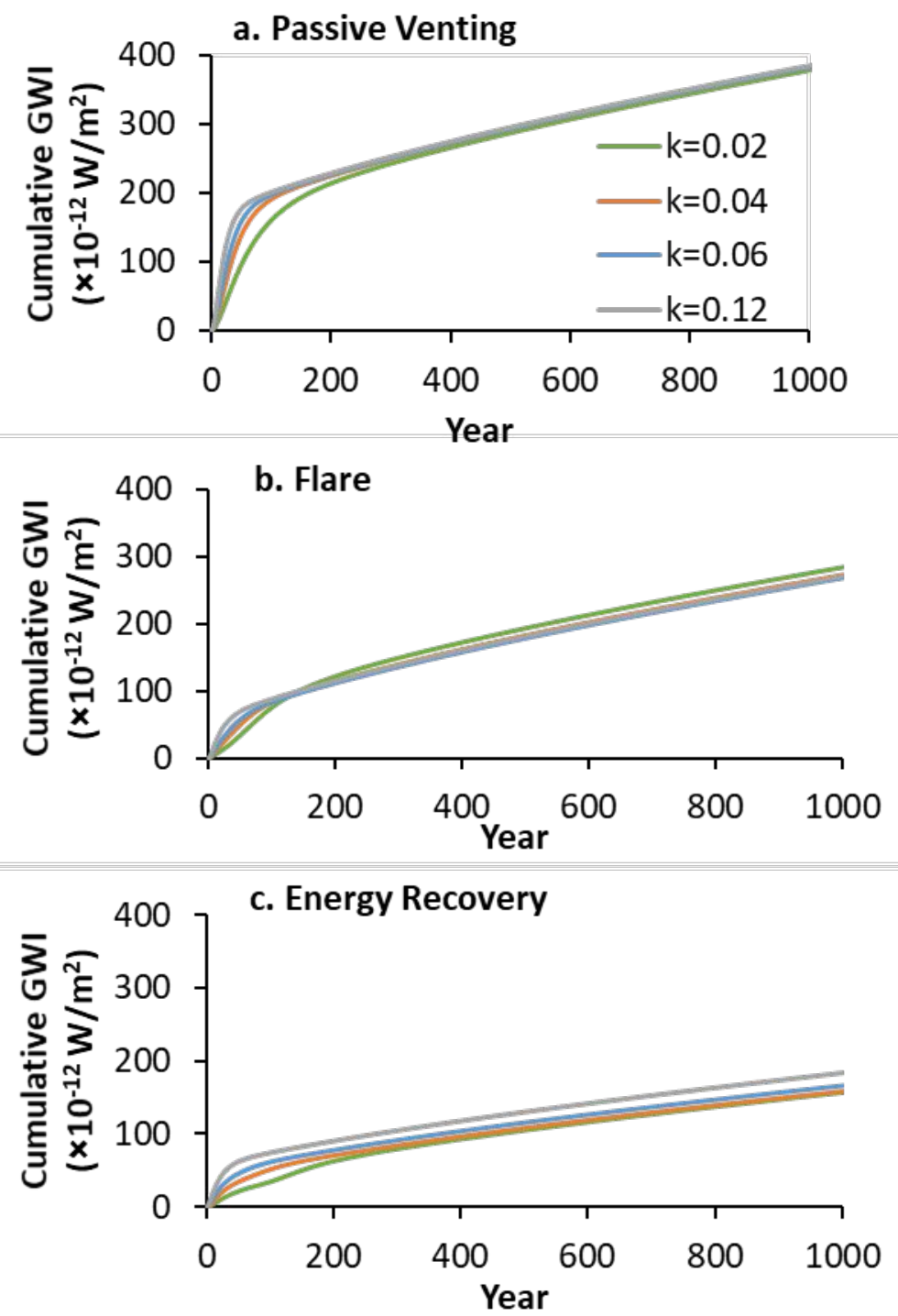

Figure S8. Cumulative radiative forcing based on Positive $\mathrm{CO}_{2} \mathrm{~b}$ accounting for four decay rates and three gas treatment scenarios. 

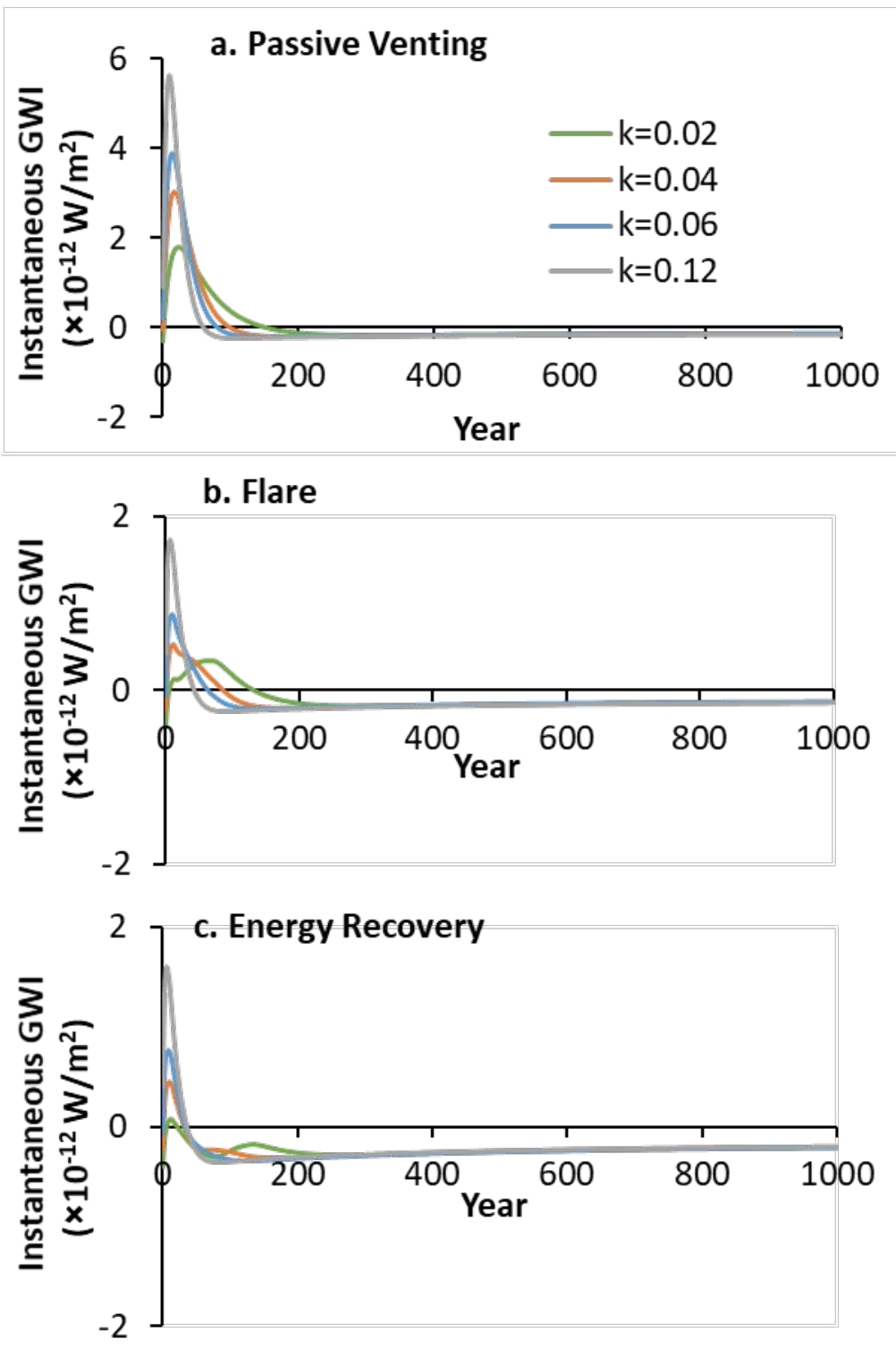

Figure S9. Instantaneous radiative forcing based on Neutral $\mathrm{CO}_{2} \mathrm{~b}$ accounting for four decay rates and three gas treatment scenarios. 

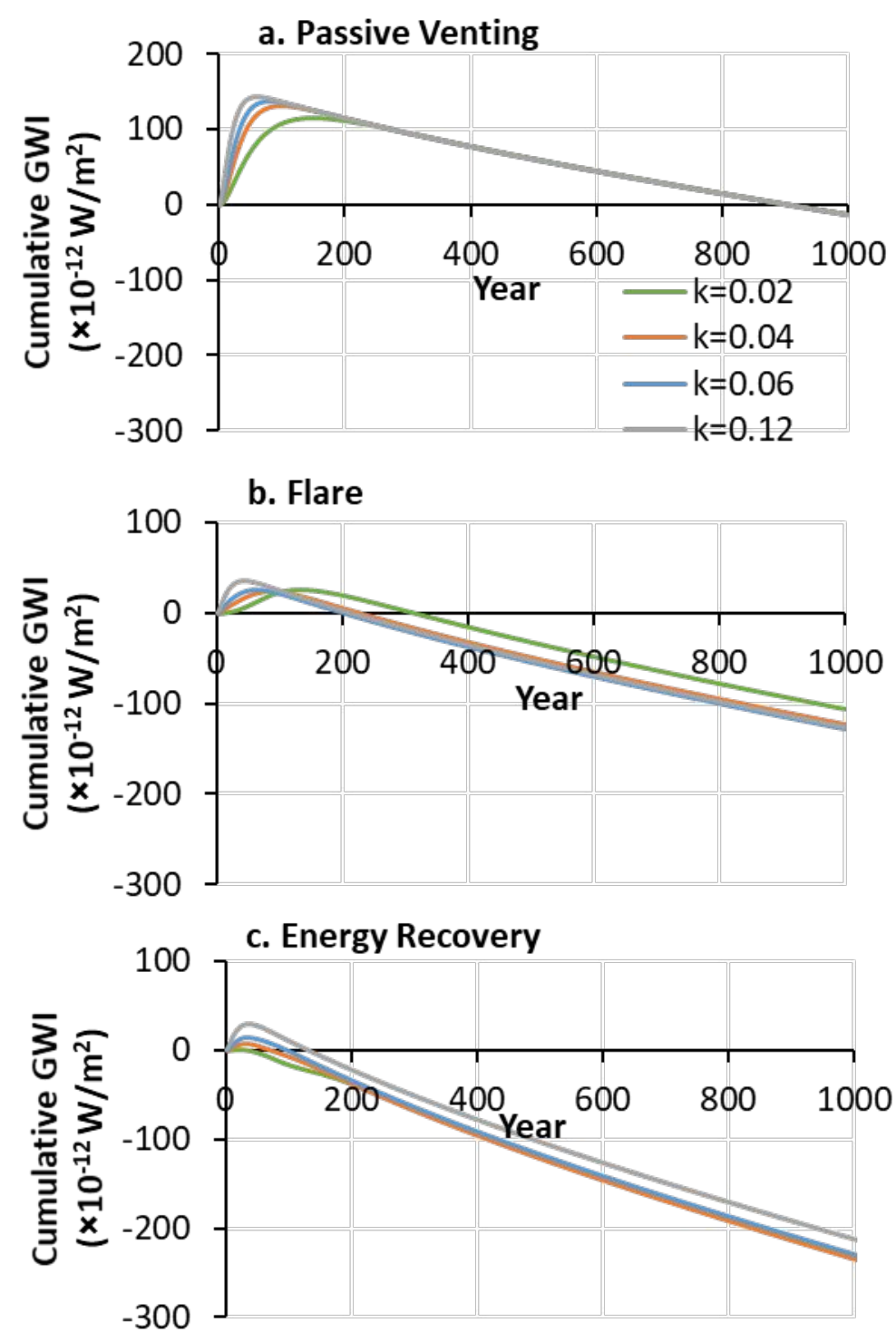

Figure S10. Cumulative radiative forcing based on Neutral $\mathrm{CO}_{2} \mathrm{~b}$ accounting for four decay rates and three gas treatment scenarios. 


\subsection{Sensitivity Analysis}
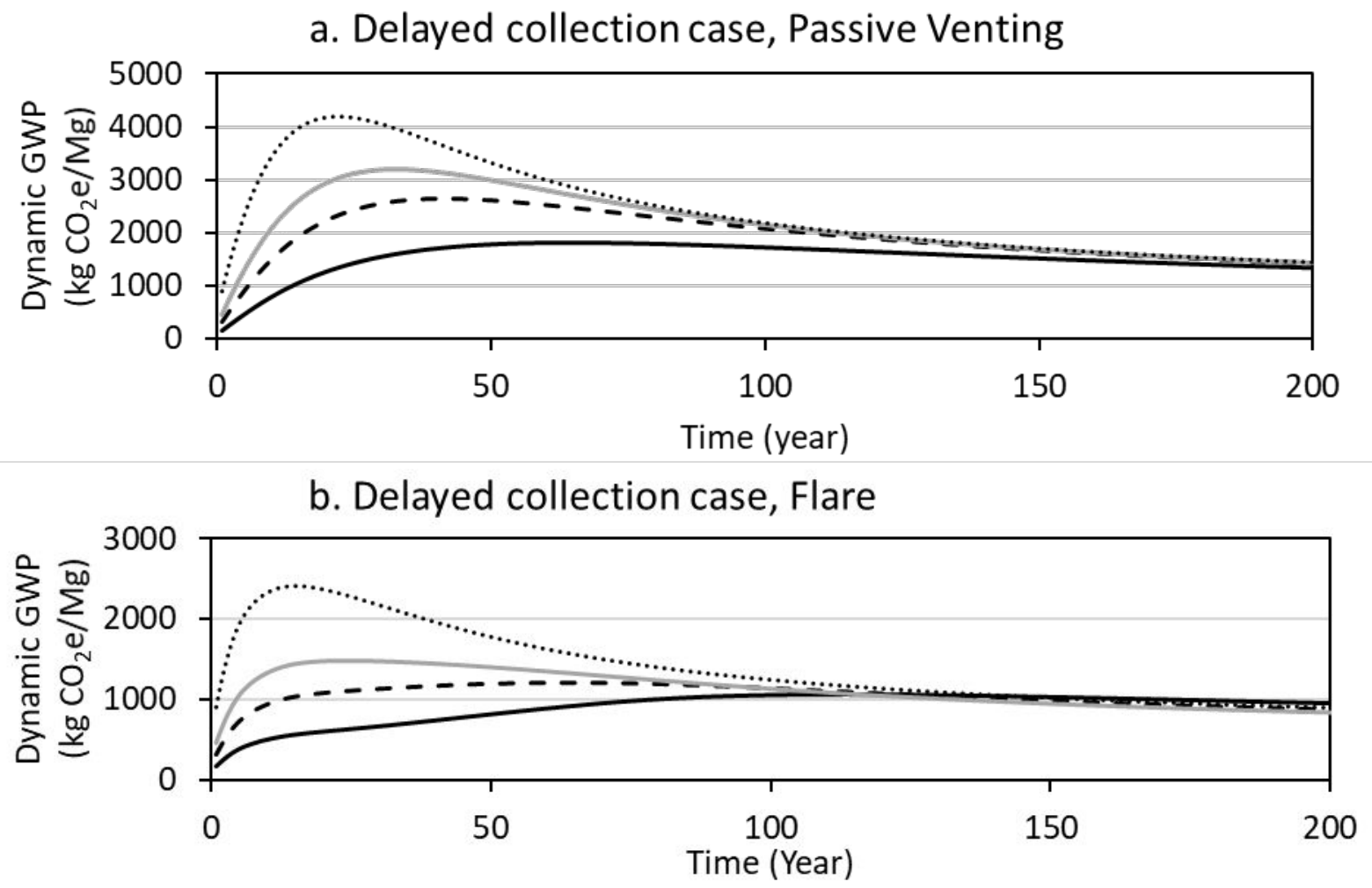

c. Delayed collection case, Energy Recovery

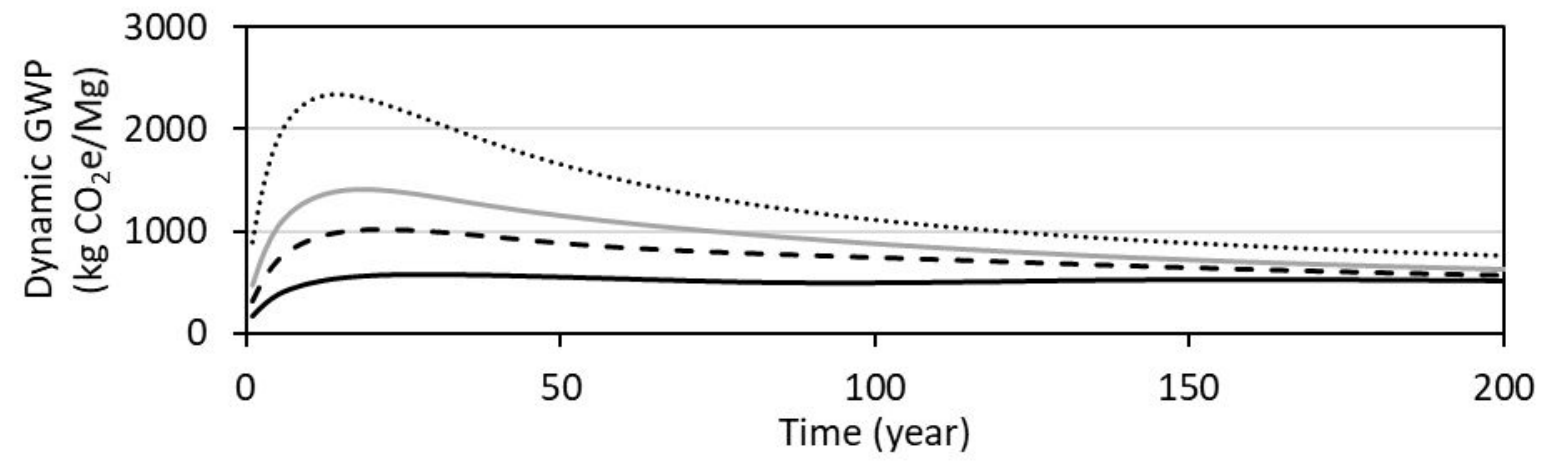

Figure S11. Dynamic global warming potentials for each gas control scenario and decay rate using "delayed" collection case where the installation of collection system was delayed from year 2 to year 10 . 


\section{a. Time Horizon $=100$ years}

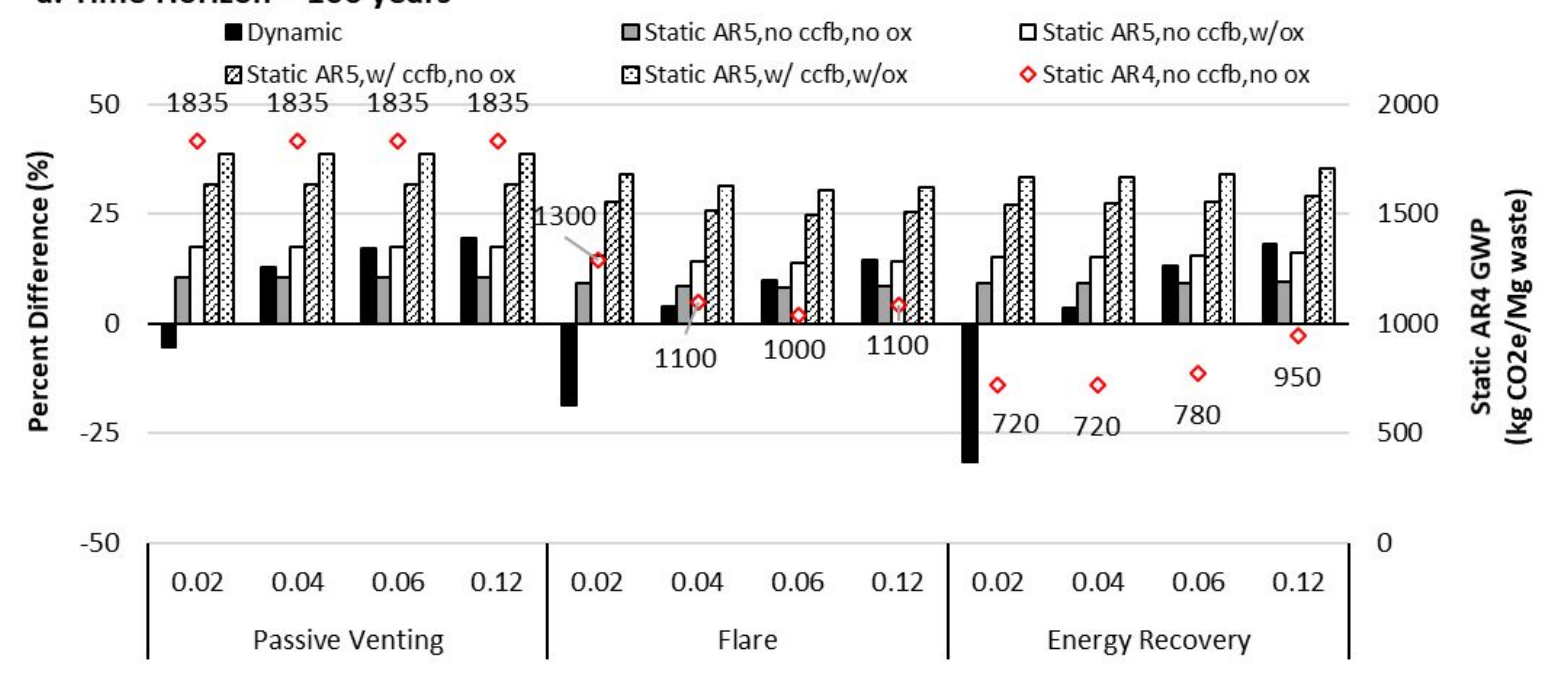

b. Time Horizon $=\mathbf{2 0}$ years

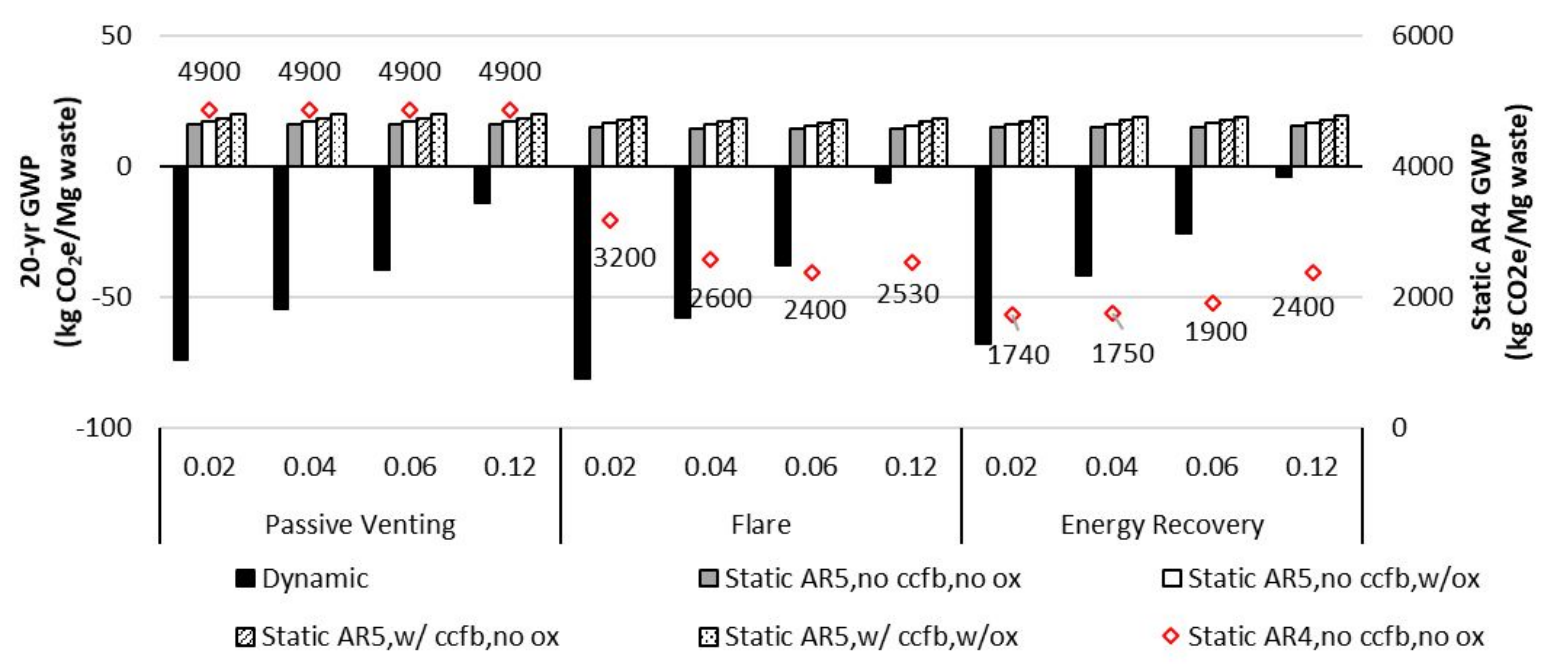

Figure S12. Static AR4 GWP estimates for each decay rate and gas management case under "delayed" collection case and Positive $\mathrm{CO}_{2} \mathrm{~b}$ (red diamonds; $2^{\text {nd }} \mathrm{y}$-axis) and the percent difference of the dynamic and AR5 static GWP relative to the static AR4 GWP values (a - 100-yr; b - 20-yr). ox - the methane oxidation effect; ccfb - climate carbon feedback. 
Table S5. Comparative Results for Default Collection (gas collection starts at year 2) and Delayed Collection (gas collection starts at year 10) Cases. Static GWPs are based on AR5 values considering $\mathrm{CH}_{4}$ oxidation effect, consistent with dynamic GWP accounting.

\begin{tabular}{|c|c|c|c|c|}
\hline & $\begin{array}{c}\text { Decay Rate } \\
k\end{array}$ & $\begin{array}{c}\text { Default } \\
\text { Collection }\end{array}$ & $\begin{array}{c}\text { Delayed } \\
\text { Collection }\end{array}$ & $\begin{array}{c}\% \\
\text { Difference } \\
\end{array}$ \\
\hline \multicolumn{5}{|l|}{ Peak year for dynamic GWPs (yr) } \\
\hline \multirow[t]{4}{*}{ Flare scenarios } & $k=0.02 \mathrm{yr}^{-1}$ & 119 & 113 & \\
\hline & $k=0.04 \mathrm{yr}^{-1}$ & 66 & 64 & \\
\hline & $k=0.06 \mathrm{yr}^{-1}$ & 35 & 24 & \\
\hline & $k=0.12 \mathrm{yr}^{-1}$ & 38 & 15 & \\
\hline \multirow[t]{4}{*}{ Energy scenarios } & $k=0.02 \mathrm{yr}^{-1}$ & 38 & 29 & \\
\hline & $k=0.04 \mathrm{yr}^{-1}$ & 26 & 21 & \\
\hline & $k=0.06 \mathrm{yr}^{-1}$ & 22 & 18 & \\
\hline & $k=0.12 \mathrm{yr}^{-1}$ & 16 & 14 & \\
\hline \multicolumn{5}{|l|}{ Peak dynamic GWPs $\left(\mathrm{kg} \mathrm{CO}_{2} \mathrm{e} / \mathrm{Mg}\right)$} \\
\hline \multirow[t]{4}{*}{ Flare scenarios } & $k=0.02 \mathrm{yr}^{-1}$ & 834 & 1060 & \\
\hline & $k=0.04 \mathrm{yr}^{-1}$ & 948 & 1207 & \\
\hline & $k=0.06 \mathrm{yr}^{-1}$ & 1112 & 1488 & \\
\hline & $k=0.12 \mathrm{yr}^{-1}$ & 1669 & 2410 & \\
\hline \multirow[t]{4}{*}{ Energy scenarios } & $k=0.02 \mathrm{yr}^{-1}$ & 429 & 573 & \\
\hline & $k=0.04 \mathrm{yr}-^{1}$ & 730 & 1023 & \\
\hline & $k=0.06 \mathrm{yr}^{-1}$ & 980 & 1412 & \\
\hline & $k=0.12 \mathrm{yr}^{-1}$ & 1558 & 2344 & \\
\hline \multicolumn{5}{|l|}{ Dynamic 100 -yr GWPs $\left(\mathrm{kg} \mathrm{CO}_{2} \mathrm{e} / \mathrm{Mg}\right)$} \\
\hline \multirow[t]{4}{*}{ Flare scenarios } & $k=0.02 \mathrm{yr}^{-1}$ & 1013 & 1053 & 4 \\
\hline & $k=0.04 \mathrm{yr}^{-1}$ & 1062 & 1138 & 7 \\
\hline & $k=0.06 \mathrm{y}^{\mathrm{r}-1}$ & 1031 & 1140 & 11 \\
\hline & $k=0.12 \mathrm{yr}^{-1}$ & 1045 & 1241 & 19 \\
\hline \multirow[t]{4}{*}{ Energy scenarios } & $k=0.02 \mathrm{yr}^{-1}$ & 445 & 491 & 10 \\
\hline & $k=0.04 \mathrm{yr}^{-1}$ & 657 & 746 & 14 \\
\hline & $k=0.06 \mathrm{yr}-^{1}$ & 745 & 877 & 18 \\
\hline & $k=0.12 \mathrm{yr}^{-1}$ & 885 & 1118 & 26 \\
\hline \multicolumn{5}{|l|}{ Dynamic $20-y r$ GWPs $\left(\mathrm{kg} \mathrm{CO}_{2} \mathrm{e} / \mathrm{Mg}\right)$} \\
\hline \multirow[t]{4}{*}{ Flare scenarios } & $k=0.02 \mathrm{yr}^{-1}$ & 484 & 596 & 23 \\
\hline & $k=0.04 \mathrm{yr}^{-1}$ & 864 & 1080 & 25 \\
\hline & $k=0.06 \mathrm{yr}^{-1}$ & 1172 & 1483 & 27 \\
\hline & $k=0.12 \mathrm{yr}^{-1}$ & 1813 & 2368 & 31 \\
\hline \multirow[t]{4}{*}{ Energy scenarios } & $k=0.02 \mathrm{yr}^{-1}$ & 444 & 562 & 27 \\
\hline & $k=0.04 \mathrm{yr}^{-1}$ & 792 & 1022 & 29 \\
\hline & $k=0.06 \mathrm{yr}^{-1}$ & 1078 & 1410 & 31 \\
\hline & $k=0.12 \mathrm{yr}^{-1}$ & 1692 & 2285 & 35 \\
\hline \multicolumn{5}{|l|}{ Static 100-yr GWPs $\left(\mathrm{kg} \mathrm{CO}_{2} \mathrm{e} / \mathrm{Mg}\right)$} \\
\hline \multirow[t]{2}{*}{ Flare scenarios } & $k=0.02 \mathrm{yr}^{-1}$ & 1453 & 1492 & 3 \\
\hline & $k=0.04 \mathrm{yr}^{-1}$ & 1179 & 1253 & 6 \\
\hline
\end{tabular}




\begin{tabular}{ccrrr}
\hline & $\begin{array}{c}\text { Decay Rate } \\
k\end{array}$ & $\begin{array}{c}\text { Default } \\
\text { Collection }\end{array}$ & $\begin{array}{c}\text { Delayed } \\
\text { Collection }\end{array}$ & $\begin{array}{c}\% \\
\text { Difference }\end{array}$ \\
\hline & $k=0.06 \mathrm{yr}^{-1}$ & 1075 & 1181 & 10 \\
& $k=0.12 \mathrm{yr}^{-1}$ & 1049 & 1238 & 18 \\
Energy scenarios & $k=0.02 \mathrm{yr}^{-1}$ & 783 & 827 & 6 \\
& $k=0.04 \mathrm{yr}^{-1}$ & 744 & 829 & 11 \\
& $k=0.06 \mathrm{yr}^{-1}$ & 770 & 893 & 16 \\
Static 20-yr GWPs (kg CO $\mathrm{e} / \mathrm{Mg})$ & $k=0.12 \mathrm{yr}^{-1}$ & 878 & 1097 & 25 \\
Flare scenarios & $k=0.02 \mathrm{yr}^{-1}$ & & & 3 \\
& $k=0.04 \mathrm{yr}^{-1}$ & 3576 & 3692 & 8 \\
& $k=0.06 \mathrm{yr}^{-1}$ & 2749 & 2971 & 13 \\
& $k=0.12 \mathrm{yr}^{-1}$ & 2433 & 2754 & 6 \\
Energy scenarios & $k=0.02 \mathrm{yr}^{-1}$ & 2356 & 2927 & 13 \\
& $k=0.04 \mathrm{yr}^{-1}$ & 1900 & 2022 & 18 \\
& $k=0.06 \mathrm{yr}^{-1}$ & 1796 & 2031 & 28 \\
\hline & $k=0.12 \mathrm{yr}^{-1}$ & 1869 & 2208 & 2771 \\
\hline
\end{tabular}



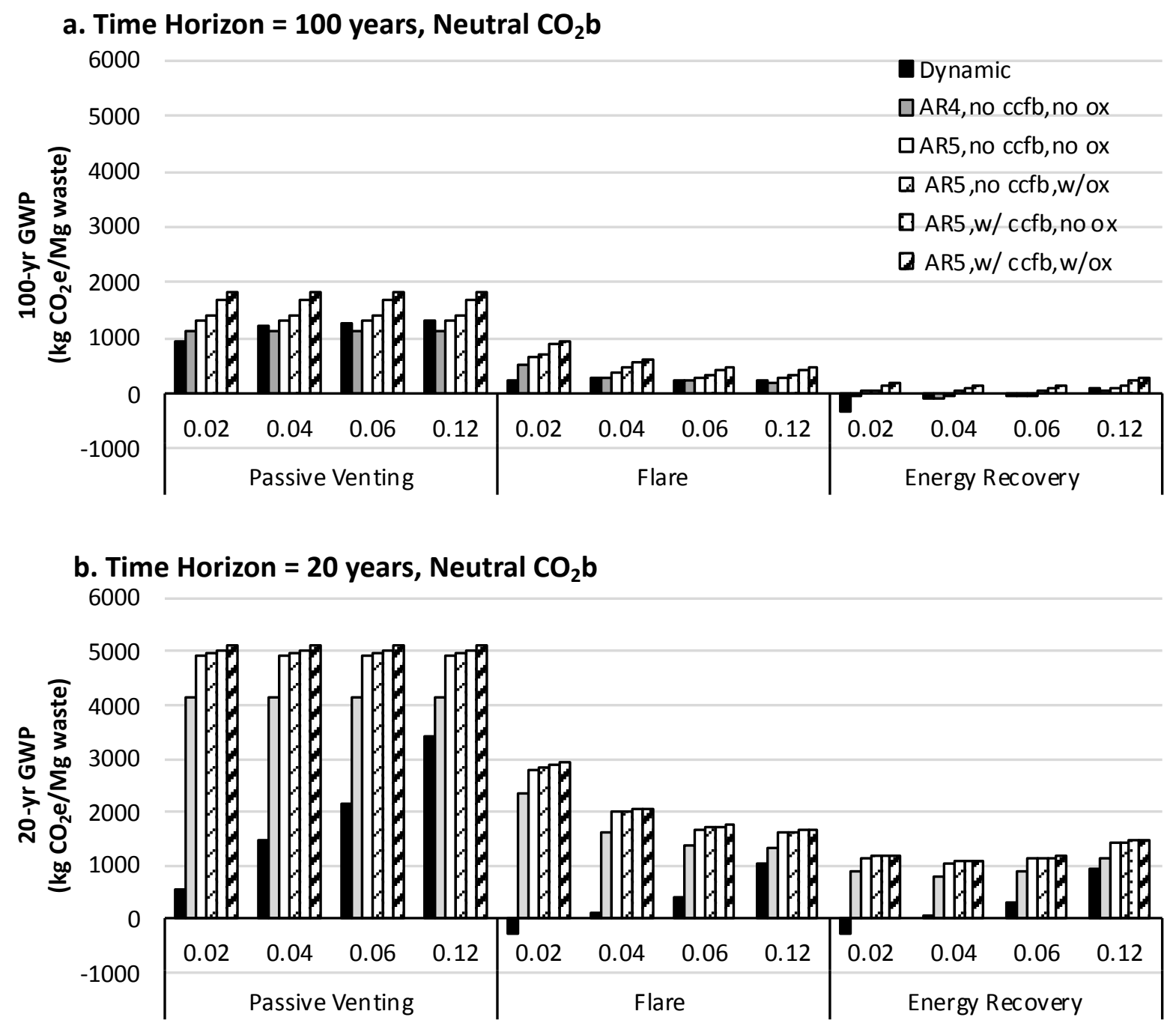

Figure S13. Static AR4 and AR5 GWP estimates for each decay rate and gas management case, compared with the dynamic GWP values ( $\mathrm{a}-100-\mathrm{yr}$; b - 20-yr) using Neutral $\mathrm{CO}_{2} \mathrm{~b}$ accounting. ox - the methane oxidation effect; ccfb - climate carbon feedback. 
Table S6. A Summary Table for GWP Estimates Based on All Scenarios Considered and Evaluated in the Study

\begin{tabular}{|c|c|c|c|c|c|c|c|c|c|c|c|c|c|c|}
\hline \multirow[b]{2}{*}{$\begin{array}{l}\text { Biogenic C } \\
\text { Accounting }\end{array}$} & \multirow[b]{2}{*}{$\begin{array}{l}\text { Gas } \\
\text { Control }\end{array}$} & \multirow[b]{2}{*}{$\begin{array}{l}\text { Decay } \\
\text { Rate } k \\
\left(\mathrm{yr}^{-1}\right)\end{array}$} & \multicolumn{5}{|c|}{ Static 100 -yr GWP ( $\mathrm{kg} \mathrm{CO}_{2} \mathrm{e} / \mathrm{Mg}$ wet waste) } & \multirow{2}{*}{$\begin{array}{c}\text { Dynamic } \\
100-\mathrm{yr} \\
\mathrm{GWP} \\
(\mathrm{kg} \\
\mathrm{CO}_{2} \mathrm{e} / \mathrm{Mg} \\
\text { wet waste) } \\
\end{array}$} & \multicolumn{5}{|c|}{ Static 20-yr GWP ( $\mathrm{kg} \mathrm{CO}_{2} \mathrm{e} / \mathrm{Mg}$ wet waste) } & \multirow[b]{2}{*}{$\begin{array}{c}\text { Dynamic } 20-\mathrm{yr} \\
\mathrm{GWP}\left(\mathrm{kg} \mathrm{CO}_{2} \mathrm{e} / \mathrm{Mg}\right. \\
\text { wet waste })\end{array}$} \\
\hline & & & $\begin{array}{l}\text { AR4, no } \\
\text { ccfb, no } \\
\text { ox }\end{array}$ & $\begin{array}{l}\text { AR5, no } \\
\text { ccfb, no } \\
\text { ox }\end{array}$ & $\begin{array}{l}\text { AR5, no } \\
\text { ccfb, w/ } \\
\text { ox }\end{array}$ & $\begin{array}{l}\text { AR5, w/ } \\
\text { ccfb, no } \\
\text { ox }\end{array}$ & $\begin{array}{l}\text { AR5, w/ } \\
\text { ccfb, w/ } \\
\text { ox }\end{array}$ & & $\begin{array}{l}\text { AR4, no } \\
\text { ccfb, no } \\
\text { ox }\end{array}$ & $\begin{array}{l}\text { AR5, no } \\
\text { ccfb, no } \\
\text { ox }\end{array}$ & $\begin{array}{l}\text { AR5, no } \\
\text { ccfb, w/ } \\
\text { ox }\end{array}$ & $\begin{array}{l}\text { AR5, w/ } \\
\text { ccfb, no } \\
\text { ox }\end{array}$ & $\begin{array}{l}\text { AR5,w/ } \\
\text { ccfb,w/ } \\
\text { ox }\end{array}$ & \\
\hline \multirow[t]{11}{*}{$\begin{array}{l}\text { Positive } \\
\mathrm{CO}_{2} \mathrm{~b}\end{array}$} & $\begin{array}{l}\text { Passive } \\
\text { Venting }\end{array}$ & $\mathrm{k}=0.02$ & 1835 & 2028 & 2157 & 2415 & 2544 & 445 & 4863 & 5637 & 5701 & 5765 & 5830 & 1279 \\
\hline & & $\mathrm{k}=0.04$ & 1835 & 2028 & 2157 & 2415 & 2544 & 657 & 4863 & 5637 & 5701 & 5765 & 5830 & 2225 \\
\hline & & $\mathrm{k}=0.12$ & 1835 & 2028 & 2157 & 2415 & 2544 & 885 & 4863 & 5637 & 5701 & 5765 & 5830 & 4189 \\
\hline & Flare & $\mathrm{k}=0.02$ & 1260 & 1376 & 1453 & 1608 & 1685 & 1013 & 3074 & 3537 & 3576 & 3615 & 3653 & 484 \\
\hline & & $\mathrm{k}=0.04$ & 1037 & 1122 & 1179 & 1293 & 1351 & 1062 & 2378 & 2720 & 2749 & 2777 & 2806 & 864 \\
\hline & & $\mathrm{k}=0.06$ & 951 & 1025 & 1075 & 1173 & 1223 & 1031 & 2112 & 2408 & 2433 & 2458 & 2482 & 1172 \\
\hline & & $\mathrm{k}=0.12$ & 930 & 1002 & 1049 & 1144 & 1192 & 1045 & 2047 & 2332 & 2356 & 2380 & 2404 & 1813 \\
\hline & $\begin{array}{l}\text { Energy } \\
\text { Recover } \\
\mathrm{y}\end{array}$ & $\mathrm{k}=0.02$ & 681 & 742 & 783 & 864 & 905 & 1739 & 1636 & 1880 & 1900 & 1920 & 1940 & 444 \\
\hline & & $\mathrm{k}=0.04$ & 648 & 706 & 744 & 821 & 859 & 2071 & 1547 & 1777 & 1796 & 1815 & 1834 & 792 \\
\hline & & $\mathrm{k}=0.06$ & 670 & 730 & 770 & 850 & 890 & 2148 & 1609 & 1849 & 1869 & 1889 & 1909 & 1078 \\
\hline & & $\mathrm{k}=0.12$ & 761 & 831 & 878 & 972 & 1019 & 2190 & 1862 & 2143 & 2167 & 2190 & 2213 & 1692 \\
\hline \multirow[t]{11}{*}{$\begin{array}{l}\text { Neutral } \\
\mathrm{CO}_{2} \mathrm{~b}\end{array}$} & $\begin{array}{l}\text { Passive } \\
\text { Venting }\end{array}$ & $\mathrm{k}=0.02$ & 1100 & 1293 & 1422 & 1680 & 1809 & 913 & 4128 & 4902 & 4966 & 5030 & 5095 & 530 \\
\hline & & $\mathrm{k}=0.04$ & 1100 & 1293 & 1422 & 1680 & 1809 & 1214 & 4128 & 4902 & 4966 & 5030 & 5095 & 1464 \\
\hline & & $\mathrm{k}=0.06$ & 1100 & 1293 & 1422 & 1680 & 1809 & 1279 & 4128 & 4902 & 4966 & 5030 & 5095 & 2163 \\
\hline & & $\mathrm{k}=0.12$ & 1100 & 1293 & 1422 & 1680 & 1809 & 1308 & 4128 & 4902 & 4966 & 5030 & 5095 & 3400 \\
\hline & Flare & $\mathrm{k}=0.02$ & 525 & 641 & 718 & 873 & 950 & 239 & 2339 & 2802 & 2841 & 2880 & 2918 & -256 \\
\hline & & $\mathrm{k}=0.04$ & 302 & 387 & 444 & 558 & 615 & 280 & 1643 & 1985 & 2014 & 2042 & 2071 & 119 \\
\hline & & $\mathrm{k}=0.06$ & 216 & 290 & 340 & 438 & 488 & 247 & 1377 & 1673 & 1698 & 1723 & 1747 & 423 \\
\hline & & $\mathrm{k}=0.12$ & 195 & 267 & 314 & 409 & 457 & 255 & 1312 & 1597 & 1621 & 1645 & 1669 & 1055 \\
\hline & $\begin{array}{l}\text { Energy } \\
\text { Recover } \\
\mathrm{y}\end{array}$ & $\mathrm{k}=0.02$ & -54 & 7 & 48 & 129 & 169 & -311 & 901 & 1144 & 1165 & 1185 & 1205 & -296 \\
\hline & & $\mathrm{k}=0.06$ & -65 & -5 & 35 & 115 & 155 & -31 & 874 & 1114 & 1134 & 1154 & 1174 & 329 \\
\hline & & $\mathrm{k}=0.12$ & 26 & 96 & 143 & 237 & 284 & 95 & 1127 & 1408 & 1431 & 1455 & 1478 & 934 \\
\hline
\end{tabular}



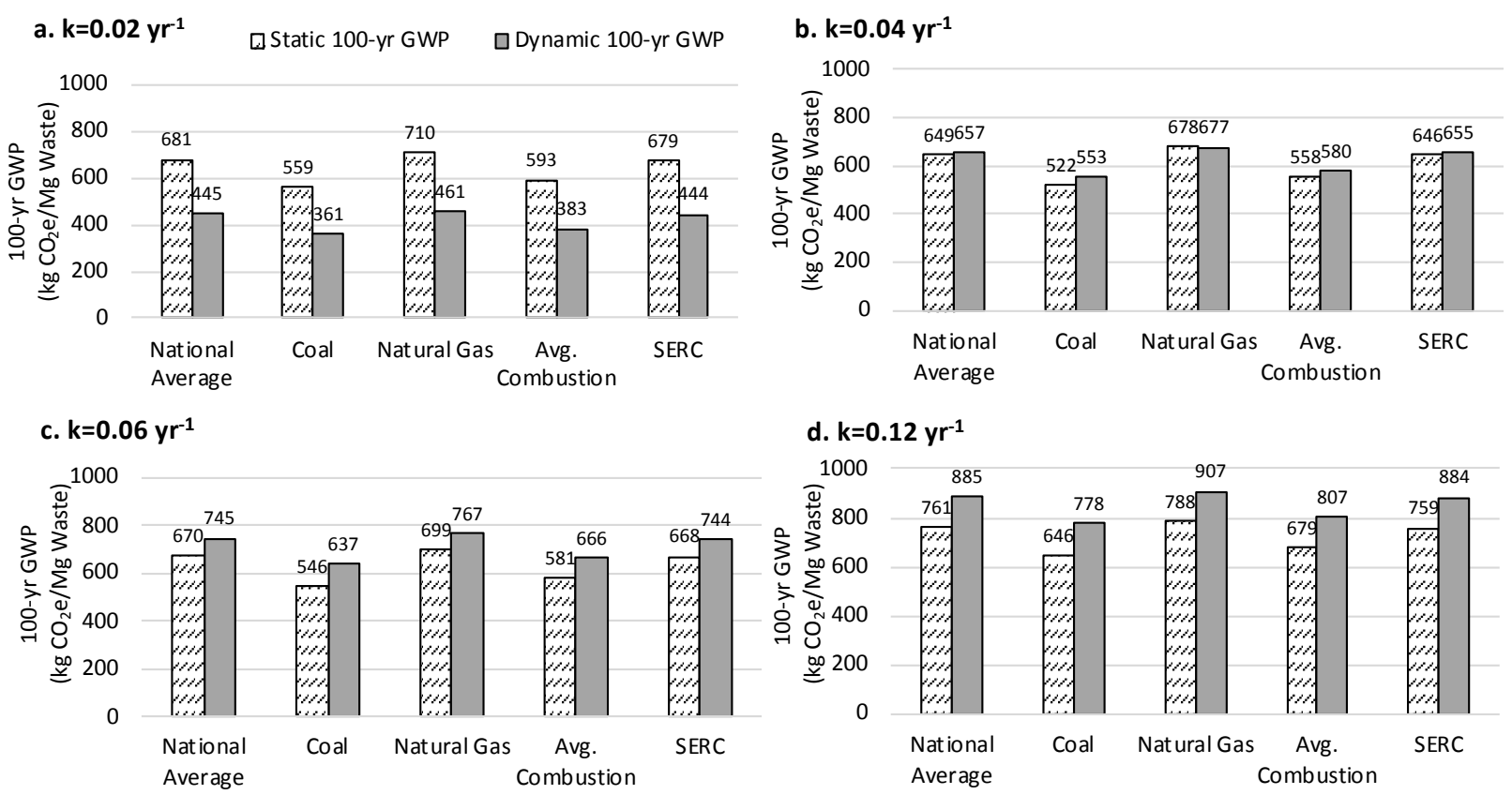

Figure S14. Effect of electricity source on static (AR4) and dynamic global warming potentials using Positive $\mathrm{CO}_{2} \mathrm{~b}$ accounting for four decay rates. The greenhouse gas intensity for each offset electricity source is given in Table S3.
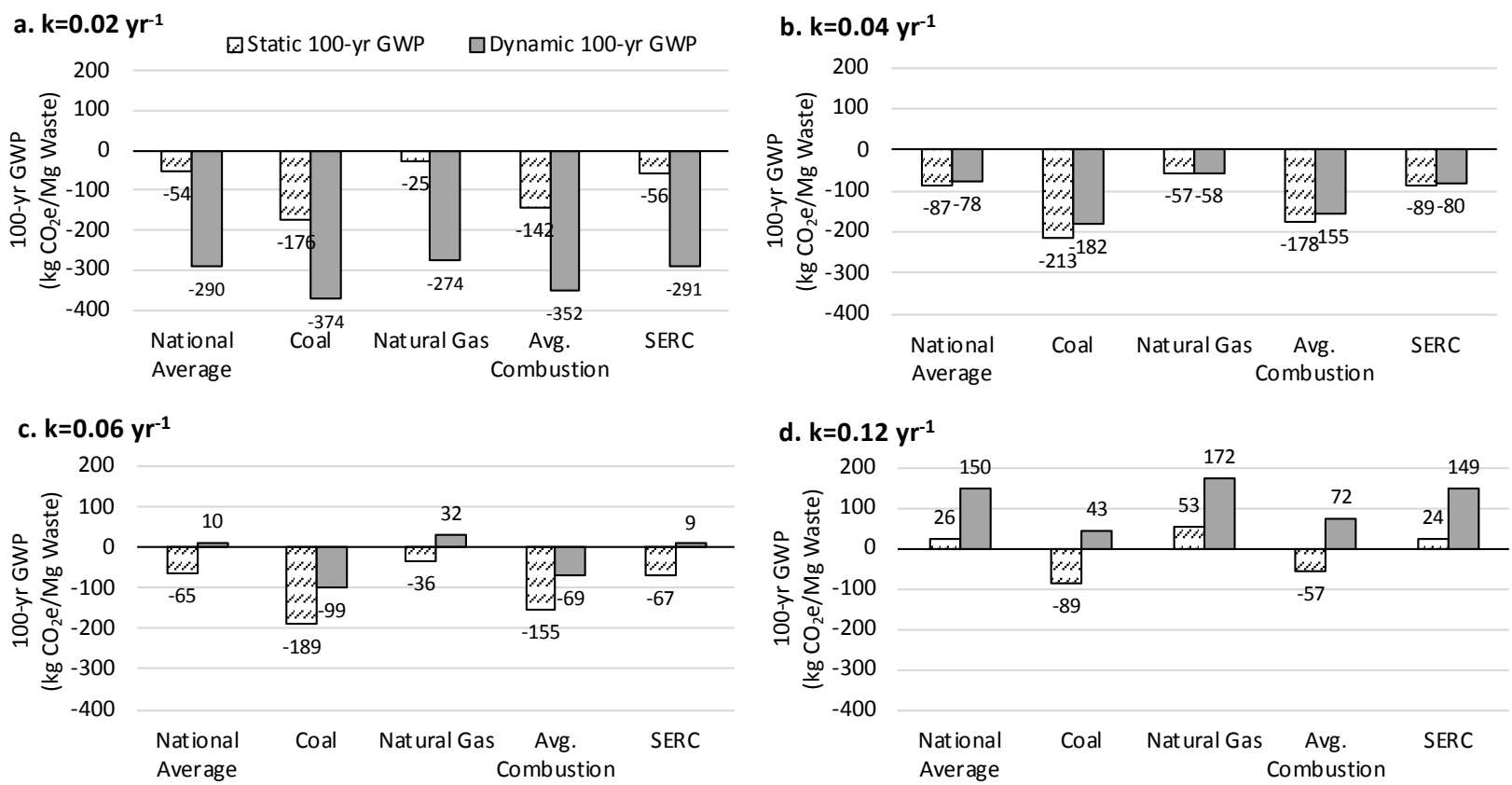

Figure S15. Effect of electricity source on static (AR4) and dynamic global warming potentials based on Neutral $\mathrm{CO}_{2} \mathrm{~b}$ accounting for four decay rates. The greenhouse gas intensity for each offset electricity source is given in Table S3. 
a. Static $\mathbf{G W P} \mathbf{2 0}_{\mathbf{2 0}}$, Passive Venting

(kg CO $2 \mathrm{e} / \mathrm{Mg}$ waste)

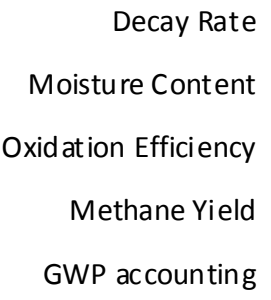

-High $\square$ Low 100020003000400050006000

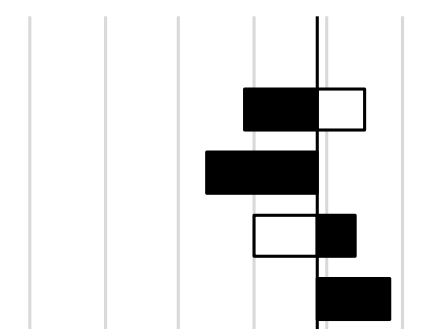

b. Static $\mathbf{G W P}_{20}$, Flare
$1000 \quad 2000 \quad 3000 \quad 4000$

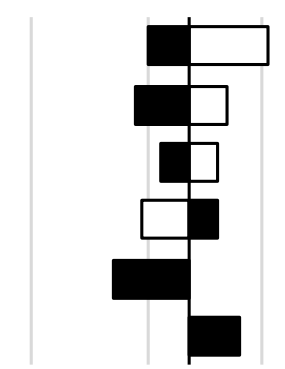

c. Static $\mathbf{G W P}_{\mathbf{2 0}}$, Energy Recovery

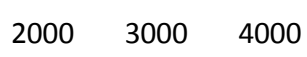

1000

Decay Rate

Collection Efficiency

Moisture Content

Oxidation Efficiency

Methane Yield

Elec. Emission Factor of CO2-fossil

Energy Gen. Efficiency

GWP accounting

d. Dynamic GWP ${ }_{20}$, Passive Venting

0100020003000400050006000

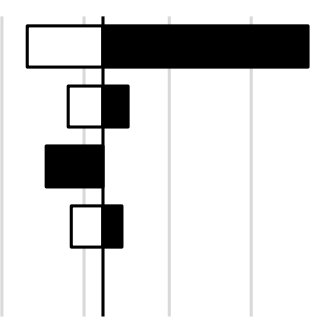

e. Dynamic GWP ${ }_{20}$, Flare

$\begin{array}{lllll}0 & 1000 & 2000 & 3000 & 4000\end{array}$

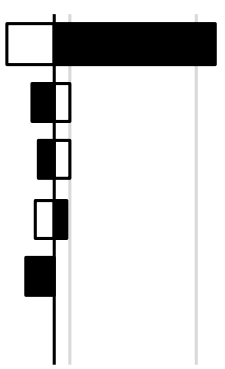

f. Dynamic GWP ${ }_{20}$, Energy Recovery $\begin{array}{lllll}0 & 1000 & 2000 & 3000 & 4000\end{array}$

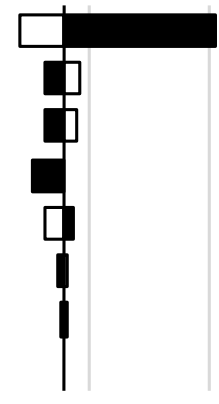

Figure S16. Ranges of static and dynamic 20-yr GWPs based on Positive $\mathrm{CO}_{2} \mathrm{~b}$ accounting. The default value of each input defines the baseline shown in the middle separating the lower and upper bound. The black and white bars refer to the GWP estimates using the maximum and minimum values for each input in Table S2, respectively. "Static $\mathrm{CH}_{4} \mathrm{GWP}$ " refers to the choices of GWP values from the AR4 and AR5 (e.g., the lower bound results from the AR4 $\mathrm{CH}_{4}$ $=25$ ] while the upper bound from the AR5 including oxidation effect of $\mathrm{CH}_{4}$ and climate carbon feedback $\left.\left[\mathrm{CH}_{4}=36\right]\right)$. 
a. Static GWP 100 , Passive Venting ( $\mathrm{kg} \mathrm{CO} 2 \mathrm{e} / \mathrm{Mg}$ waste) 0

500

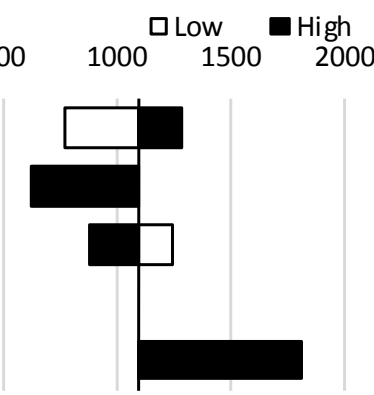

b. Static $\mathbf{G W P}_{100}$, Flare

Methane Yield

Oxidation Efficiency

Moisture Content

Decay Rate

Static $\mathrm{CH} 4$ GWP

$$
\begin{array}{r}
\text { Methane Yield } \\
\text { Oxidation Efficiency } \\
\text { Collection Efficiency } \\
\text { Moisture Content } \\
\text { Decay Rate } \\
\text { Static CH4 GWP }
\end{array}
$$

$0 \quad 500 \quad 1000$

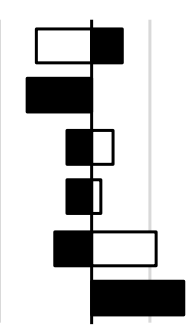

d. Dynamic GWP $\mathbf{P}_{100}$, Passive Venting

$\begin{array}{lllll}0 & 500 & 1000 & 1500 & 2000\end{array}$

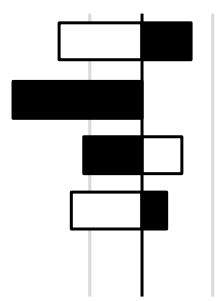

e. Dynamic GWP $_{100}$, Flare

$\begin{array}{llll}-500 & 0 & 500 & 1000\end{array}$

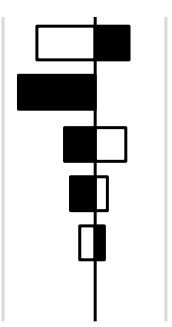

f. Dynamic GWP ${ }_{100}$, Energy Recovery

1000
500

1000

c. Static GWP ${ }_{100}$, Energy Recovery

Decay Rate

Collection Efficiency

Methane Yield

Oxidation Efficiency

Elec. Emission Factor of $\mathrm{CO} 2$-fossil

Energy Gen. Efficiency

Moisture Content

Static $\mathrm{CH} 4$ GWP
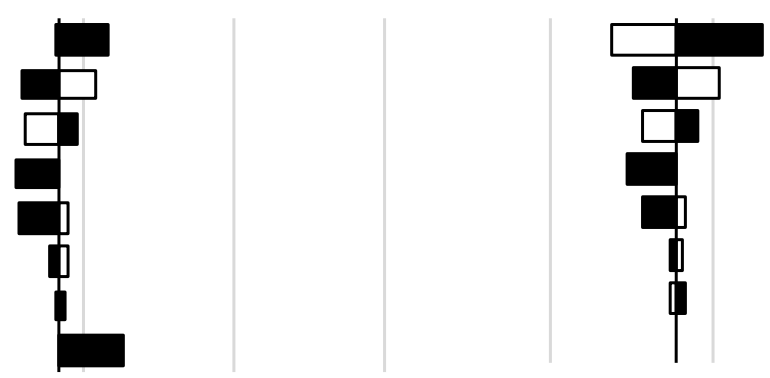

Figure S17. Ranges of static and dynamic 100-yr GWPs based on Neutral $\mathrm{CO}_{2} \mathrm{~b}$ accounting. The default value of each input defines the baseline shown in the middle separating the lower and upper bound. The black and white bars refer to the GWP estimates using the maximum and minimum values for each input in Table S2, respectively. "Static $\mathrm{CH}_{4} \mathrm{GWP}$ " refers to the choices of GWP values from the AR4 and AR5 (e.g., the lower bound results from the AR4 $\left[\mathrm{CH}_{4}=25\right]$ while the upper bound from the AR5 including oxidation effect of $\mathrm{CH}_{4}$ and climate carbon feedback $\left[\mathrm{CH}_{4}\right.$ $=36]$ ). 


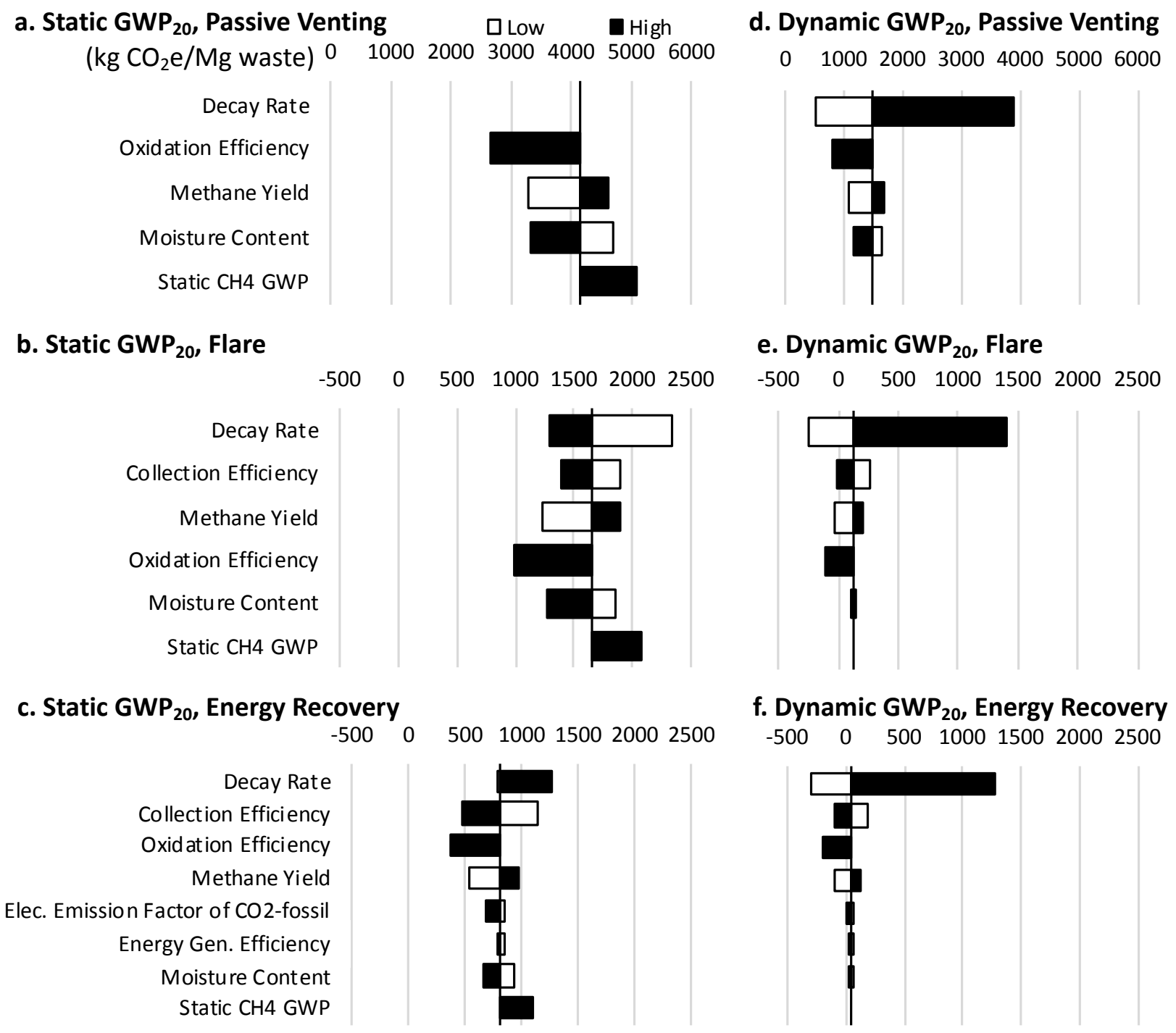

Figure S18. Ranges of static and dynamic 20-yr GWPs based on Neutral $\mathrm{CO}_{2} \mathrm{~b}$ accounting. The default value of each input defines the baseline shown in the middle separating the lower and upper bound. The black and white bars refer to the GWP estimates using the maximum and minimum values for each input in Table S2, respectively. "Static $\mathrm{CH}_{4}$ GWP" refers to the choices of GWP values from the AR4 and AR5 (e.g., the lower bound results from the AR4 $\left[\mathrm{CH}_{4}=25\right]$ while the upper bound from the AR5 including oxidation effect of $\mathrm{CH}_{4}$ and climate carbon feedback $\left[\mathrm{CH}_{4}\right.$ $=36]$ ). 
a. Time Horizon = 100 years,

Positive $\mathrm{CO}_{2} \mathrm{~b}$, Passive Venting

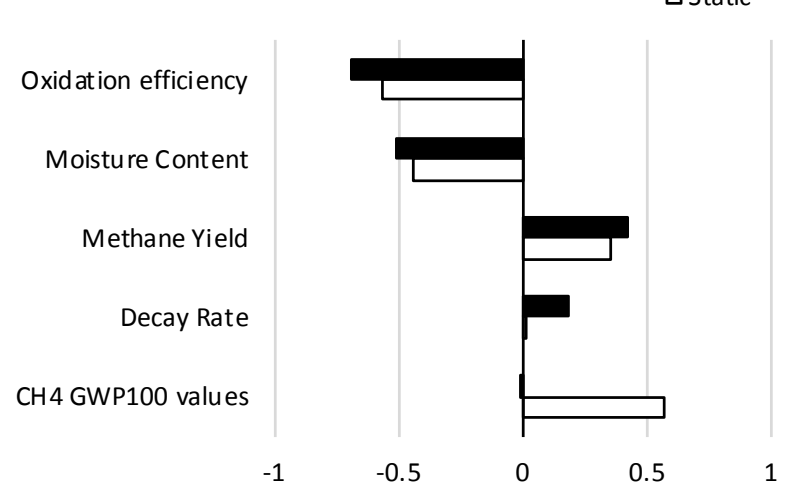

c. Time Horizon = 100 years, Neutral $\mathrm{CO}_{2} \mathrm{~b}$, Passive Venting

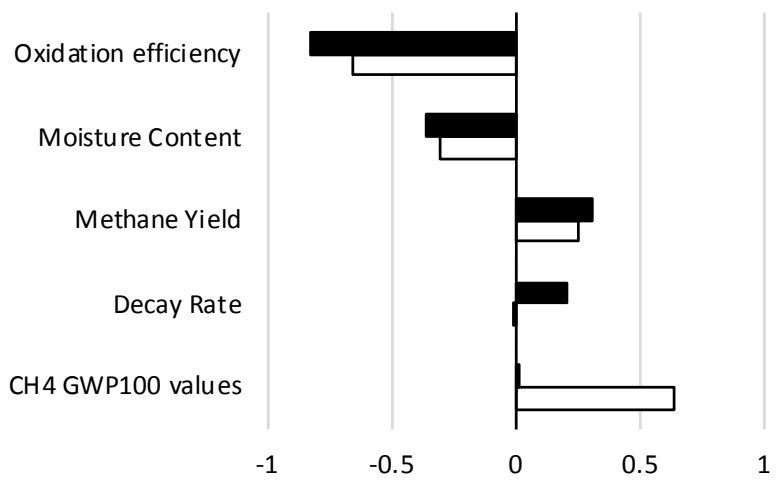

b. Time Horizon = 20 years, Positive $\mathrm{CO}_{2} \mathrm{~b}$, Passive Venting

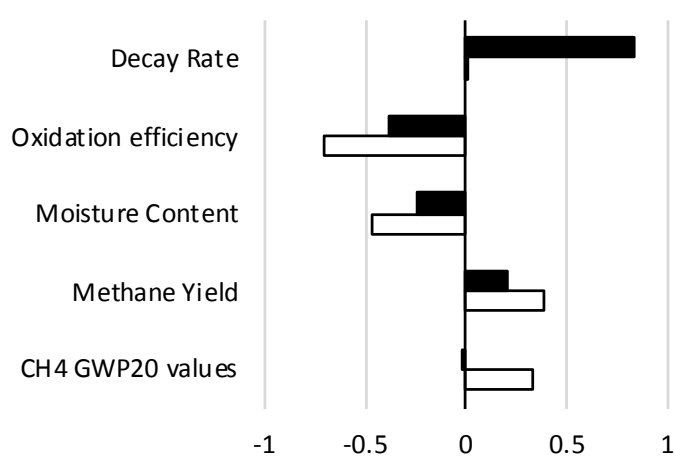

d. Time Horizon $=\mathbf{2 0}$ years, Neutral $\mathrm{CO}_{2} \mathrm{~b}$, Passive Venting

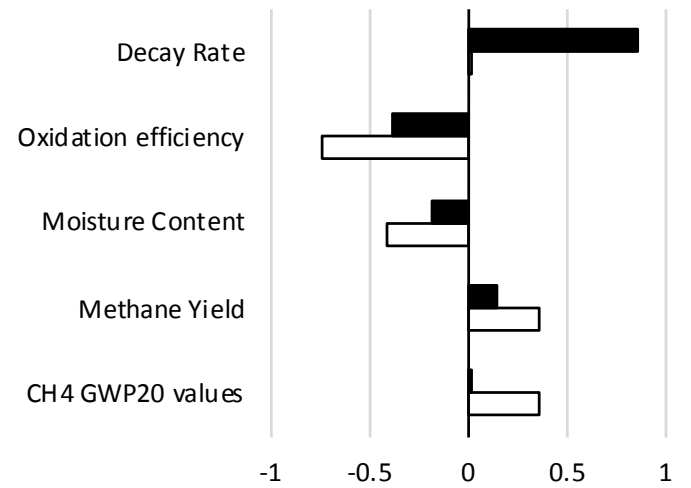

Figure S19. Correlation coefficients between model inputs and GWPs associated with the landfills

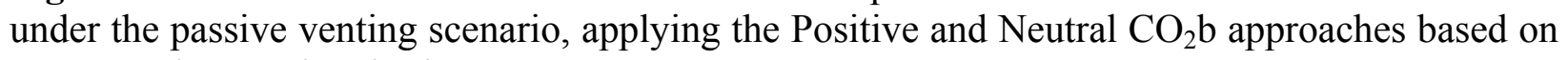
100-yr and 20-yr time horizon. 
a. Time Horizon $=100$ years, Positive $\mathrm{CO}_{2} \mathrm{~b}$, Flare

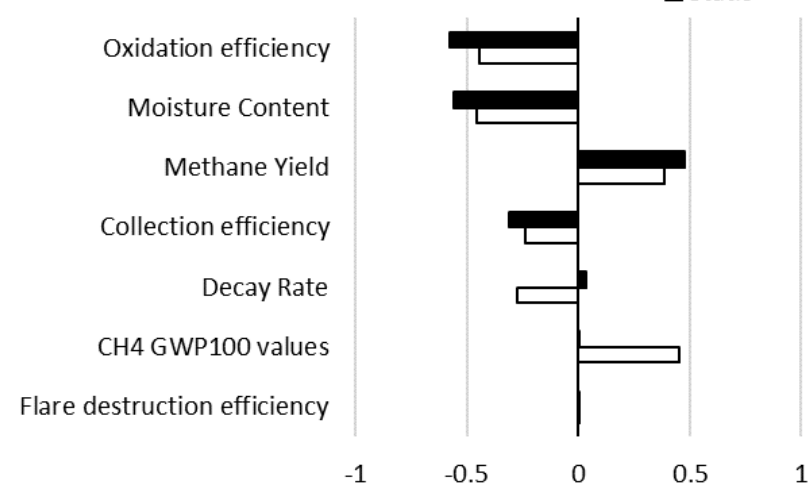

c. Time Horizon $=100$ years, Neutral $\mathrm{CO}_{2} \mathrm{~b}$, Flare

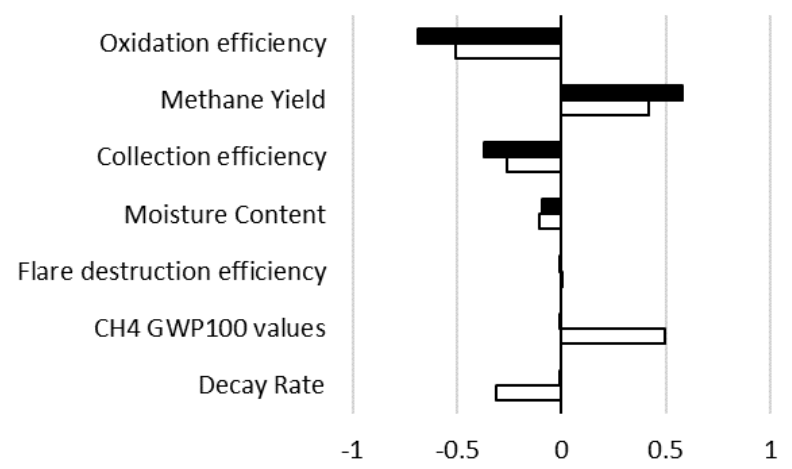

b. Time Horizon $=20$ years, Positive $\mathrm{CO}_{2} \mathrm{~b}$, Flare

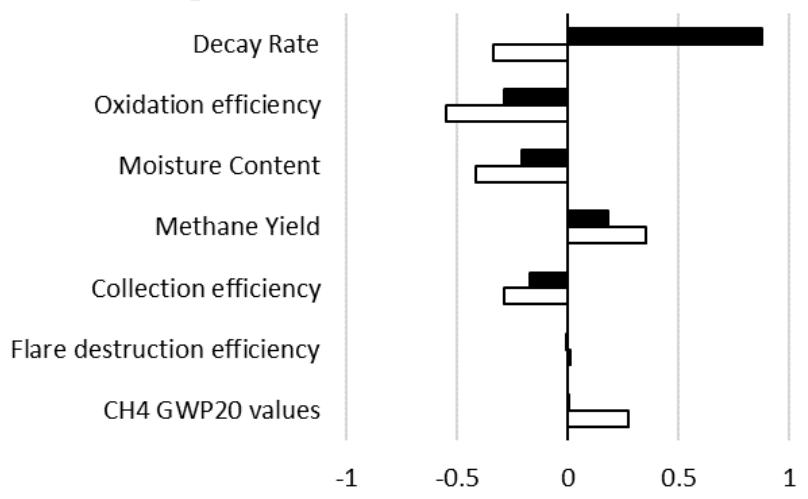

d. Time Horizon $=20$ years, Neutral $\mathrm{CO}_{2} \mathrm{~b}$, Flare

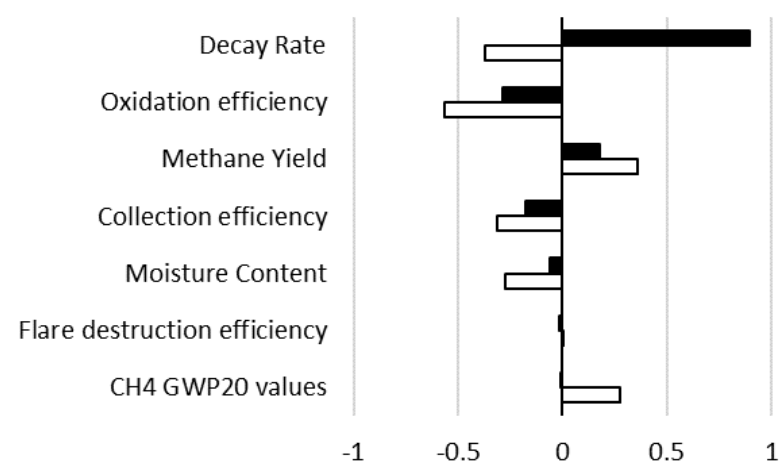

Figure S20. Correlation coefficients between model inputs and GWPs associated with the landfills under the flare scenario, applying the Positive and Neutral $\mathrm{CO}_{2} \mathrm{~b}$ approaches based on 100 -yr and 20 -yr time horizon. 
a. Time Horizon $=100$ years,

Positive $\mathrm{CO}_{2} \mathrm{~b}$, Energy Recovery

Decay Rate

Oxidation efficiency

Collection efficiency

Moisture Content

Methane Yield

Electricitv emission factor

Energy Gen. Efficiency

Energy destruction efficiency

$\mathrm{CH} 4$ GWP100 values

Flare destruction efficiency

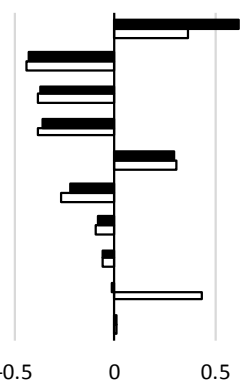

$-0.5$

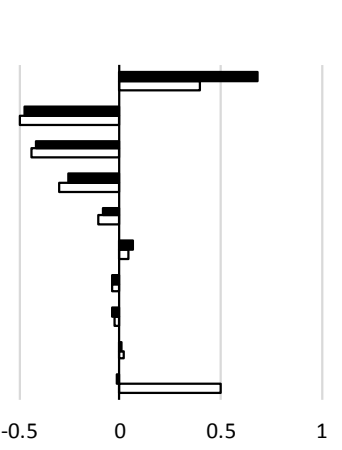

b. Time Horizon $\mathbf{=} \mathbf{2 0}$ years, Positive $\mathrm{CO}_{2} \mathrm{~b}$, Energy Recovery

Dynamic

$\square$ Static

Decay Rate

Oxidation efficiency

Moisture Content

Collection efficiency

Methane Yield

Electricity emission factor

Energy Gen. Efficiency

Energy destruction efficiency

Flare destruction efficiency

$\mathrm{CH} 4$ GWP20 values

1

c. Time Horizon $\mathbf{1} \mathbf{1 0 0}$ years, Neutral $\mathrm{CO}_{2}$ b, Energy Recovery

Oxidation efficiency

Collection efficiency

Electricity emission factor

Energy Gen. Efficiency

Moisture Content

Energy destruction efficiency

Methane Yield

Flare destruction efficiency

CH4 GWP100 values d. Time Horizon $\mathbf{2} \mathbf{2 0}$ years, Neutral $\mathrm{CO}_{2} \mathrm{~b}$, Energy Recovery Decay Rate

Oxidation efficiency Collection efficiency Methane Yield Moisture Content

Electricity emission factor Energy destruction efficiency Energy Gen. Efficiency Flare destruction efficiency CH4 GWP100 values

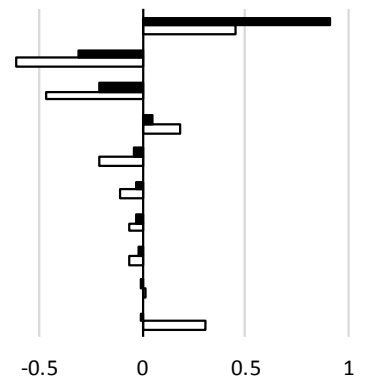

Figure S21. Correlation coefficients between model inputs and GWPs associated with the landfills under the energy recovery scenario, applying the Positive and Neutral $\mathrm{CO}_{2} \mathrm{~b}$ approaches based on 100-yr and 20-yr time horizon. 


\section{REFERENCES}

(1) Levis, J. W.; Barlaz, M. A. Is Biodegradability a Desirable Attribute for Discarded Solid Waste? Perspectives from a National Landfill Greenhouse Gas Inventory Model. Environ. Sci. Technol. 2011, 45 (13), 5470-5476. https://doi.org/10.1021/es200721s.

(2) Tchobanoglous, G.; Theisen, H.; Vigil, S. A. Integrated Solid Waste Management: Engineering Principles and Management Issues; Clark, B. J., Morriss, J. M., Eds.; McGraw-Hill: USA, 1993.

(3) Gytarsky, M. et al. IPCC - Task Force on National Greenhouse Gas Inventories; Paris, France, 2006.

(4) Jens E. Frøiland Jensen; Pipatti, R. IPCC Good Practice Guidance and Uncertainty Management in National Greenhouse Gas Inventories: CH4 Emissions from Solid Waste Disposal; Montreal, Canada, 2001.

(5) USEPA. Landfill Methane Outreach Program Chapter 3: Project Technology Options; 2017.

(6) USEPA. Energy and the Environment: Emissions \& Generation Resource Integrated Database (eGRID) https://www.epa.gov/energy/emissions-generation-resource-integrateddatabase-egrid (accessed Jun 8, 2018).

(7) USEPA. Chapter 2: Solid Waste Disposal, AP 42, Fifth Edition, Volume I.

(8) Chanton, J. P.; Powelson, D. K.; Green, R. B. Methane Oxidation in Landfill Cover Soils, Is a 10\% Default Value Reasonable? J. Environ. Qual. 2009, 38 (2), 654. https://doi.org/10.2134/jeq2008.0221.

(9) SCS Engineers. Current MSW Industry Position and State of the Practice on Methane Destruction Efficiency in Flares, Turbines, and Engines; Sacramento, 2007.

(10) Forster, P., V. Ramaswamy, P. Artaxo, T. Berntsen, R. Betts, D.W. Fahey, J. Haywood, J. Lean, D.C. Lowe, G. Myhre, J. Nganga, R. P.; G. Raga, M. S. and R. V. D. Changes in Atmospheric Constituents and in Radiative Forcing. In: Solomon, S. (Ed.), Climate Change 2007: The Physical Science Basic. Contribution of Working Group I to the Fourth Assessment Report of the Intergovernmental Panel on Climate Change; Cambridge, United Kingdom and New York, NY, USA., 2007; Vol. 30. https://doi.org/10.1103/PhysRevB.77.220407.

(11) Intergovernmental Panel on Climate Change (IPCC). Climate Change 2013: The Physical Science Basis. Contribution of Working Group I to the Fifth Assessment Report of the Intergovernmental Panel on Climate Change; Cambridge, United Kingdom and New York, NY, USA., 2013.

(12) Levasseur, A.; Lesage, P.; Margni, M.; Deschěnes, L.; Samson, R. Considering Time in LCA: Dynamic LCA and Its Application to Global Warming Impact Assessments. Environ. Sci. Technol. 2010, 44 (8), 3169-3174. https://doi.org/10.1021/es9030003.

(13) Intergovernmental Panel on Climate Change (IPCC). Climate Change 2001: IPCC Third Assessment Report; 2001.

(14) Boucher, O.; Friedlingstein, P.; Collins, B.; Shine, K. P. The Indirect Global Warming Potential and Global Temperature Change Potential Due to Methane Oxidation. Environ. Res. Lett. 2009, 4 (4), 044007. https://doi.org/10.1088/1748-9326/4/4/044007. 